\title{
Review article: a comparison of glucagon-like peptides 1 and 2
}

\author{
P. Janssen ${ }^{\star}$, A. Rotondo ${ }^{\dagger}$, F. Mulé ${ }^{\dagger} \&$ J. Tack ${ }^{\star}$
}

*Translational Research Center for Gastrointestinal Disorders, University of Leuven, Leuven, Belgium.

${ }^{\dagger}$ Dipartimento di Scienze e Tecnologie Molecolari e Biomolecolari

(STEMBIO), Università di Palermo,

Palermo, Italy.

\section{Correspondence to:}

Prof. J. Tack, Translational Research

Center for Gastrointestinal Disorders,

University of Leuven, Herestraat 49,

B-3000 Leuven, Belgium.

E-mail: jan.tack@med.kuleuven.be

\section{Publication data}

Submitted 12 June 2012

First decision 9 July 2012

Resubmitted 20 September 2012

Accepted 29 September 2012

EV Pub Online 5 November 2012

This uncommissioned review article was subject to full peer-review.

\section{SUMMARY \\ Background \\ Recent advancements in understanding the roles and functions of gluca- gon-like peptide 1 (GLP-1) and 2 (GLP-2) have provided a basis for target- ing these peptides in therapeutic strategies.}

\begin{abstract}
Aim
To summarise the preclinical and clinical research supporting the discovery of new therapeutic molecules targeting GLP-1 and GLP-2.
\end{abstract}

\section{Methods}

This review is based on a comprehensive PubMed search, representing literature published during the past 30 years related to GLP-1 and GLP-2.

\section{Results}

Although produced and secreted together primarily from L cells of the intestine in response to ingestion of nutrients, GLP-1 and GLP-2 exhibit distinctive biological functions that are governed by the expression of their respective receptors, GLP-1R and GLP-2R. Through widespread expression in the pancreas, intestine, nervous tissue, et cetera, GLP-1Rs facilitates an incretin effect along with effects on appetite and satiety. GLP-1 analogues resistant to degradation by dipeptidyl peptidase-IV and inhibitors of dipeptidyl peptidase-IV have been developed to aid treatment of diabetes and obesity. The GLP-2R is expressed almost exclusively in the stomach and bowel. The most apparent role for GLP-2 is its promotion of growth and function of intestinal mucosa, which has been targeted for therapies that promote repair and adaptive growth. These are used as treatments for intestinal failure and related conditions.

\section{Conclusions}

Our growing understanding of the biology and function of GLP-1, GLP-2 and corresponding receptors has fostered further discovery of fundamental biological function as well as new categories of potent therapeutic medicines. 


\section{INTRODUCTION}

In the last few decades, a wealth of data have expanded our knowledge on glucagon-like peptide 1 (GLP-1) and glucagon-like peptide 2 (GLP-2) as important molecules involved in a wide variety of functions. Because the biological actions of GLP-1 and GLP-2 converge at multiple levels on the regulation of nutrient assimilation and energy homeostasis, a great deal of interest has been generated for drug development with therapeutic potential. In particular, GLP-1 analogues or inhibitors of GLP-1 breakdown have been developed largely because of their incretin effects and have been directed towards treatment of endocrine abnormalities and type 2 diabetes. ${ }^{1-3}$ In contrast, GLP-2 analogue development has primarily addressed the treatment of gastrointestinal (GI)-related disorders, such as short bowel syndrome (SBS), inflammatory bowel disease (IBD) and chemotherapeutically induced GI mucositis, largely because of the intestinotrophic effects of GLP-2 in the GI tract. ${ }^{4-6}$

In this review, a comprehensive PubMed search was conducted for literature published in the past 30 years to identify information regarding GLP-1 and GLP-2. Search terms included GLP-1 or GLP-2 in combination with intestines, colon, stomach, incretin, diabetes, receptor, exenatide, liraglutide and teduglutide. This review provides a brief overview of the synthesis and metabolism of these two peptides, followed by a detailed summary of their respective physiological effects and therapeutic potential. We will highlight that, although both GLP-1 and GLP-2 are part of the proglucagon molecule, they have vastly different biological activities. A discussion of preclinical and clinical models will be presented to help differentiate these actions. Also, a brief summary of those agents that have been approved for therapeutic use, as well as those in development, will be presented.

\section{OVERVIEW: MECHANISMS OF ACTION OF GLP-1 AND GLP-2}

\section{Synthesis}

GLP-1 and GLP-2 are co-encoded within the proglucagon gene, which in mammals, gives rise to a single mRNA transcript that is expressed in the alpha $(\alpha)$ cells of the endocrine pancreas, in the enteroendocrine L cells of the intestine and in the hypothalamus and brainstem in the central nervous system (CNS). ${ }^{1,7,8}$ Proglucagon mRNA is translated into a single 160 amino acid precursor protein, producing several biologically active proglucagon-derived peptides via tissue-specific posttranslational processing. ${ }^{1}$ In pancreatic $\alpha$ cells, proglucagon is cleaved by prohormone convertase (PC) -2 to form glucagon, the major glucagon fragment and intervening peptide (IP)-1. In the GI tract and in the brain, the processing of proglucagon, which is operated by PC1/3, results in GLP-1, GLP-2, IP-2, oxyntomodulin and glicentin formation (Figure 1). ${ }^{6,9-13}$

\section{Secretion}

GLP-1 and GLP-2 are secreted in a 1:1 ratio by enteroendocrine L cells, most of which are located in the distal ileum and colon. ${ }^{14,15}$ The chief stimulus for intestinal secretion of GLP-1 and GLP-2 is the ingestion of nutrients, including glucose, fatty acids and dietary fibre. ${ }^{16}$ GLP-1 and GLP-2 are secreted in a biphasic pattern, with an early peak followed by a longer second phase after ingestion of nutrients. ${ }^{16}$ It is likely that the early phase of GLP-1 and GLP-2 secretion is due to the stimulation of $\mathrm{L}$ cells by various neural and endocrine factors, in contrast with the second or late phase, which is caused by direct stimulation of intestinal L cells by digested nutrients. ${ }^{17-19}$ After ingestion of nutrients, plasma levels of GLP-1 and GLP-2 increase 2- to 5-fold, depending on the size and nutrient composition of the meal. ${ }^{19,} 20$ The peptides diffuse across the subepithelial lamina propria to activate afferent nerves and/or enter the circulation; thus they may act as paracrine agents as well as endocrine hormones (Figure 2). ${ }^{21}$

The mechanisms by which nutrients induce the release of peptides from the enteroendocrine cells have not been fully elucidated. One mechanism that has been described involves enteroendocrine cell activation to release GLP-1 and is mediated by cellular uptake and intracellular metabolism of glucose. This triggers peptide exocytosis via ATP-sensitive potassium-channel closure, depolarisation and calcium-channel activation, similar to insulin secretion. ${ }^{22}$ However, little is known about the cellular mechanisms responsible for GLP-2 secretion. Because they are both secreted in parallel from the intestinal L cells, ${ }^{15}$ GLP-1 and GLP-2 secretion mechanisms are considered analogous.

Nutrient ingestion is the primary stimulus for secretion, but because L cells are located distally, the initial rapid rise is mediated indirectly through a neuro/endocrine pathway. In the rodent model, it appears that glucose-dependent insulinotropic polypeptide (GIP) is implicated in the secretion of GLP-1, as well as the vagus nerve, because vagotomy totally abrogated this effect. ${ }^{23}$ Acetylcholine has also been identified as a key neurotransmitter mediating the proximal-distal loop, ${ }^{24}$ suggesting that secretion in rodents is mediated through the 


\section{P. Janssen et al.}

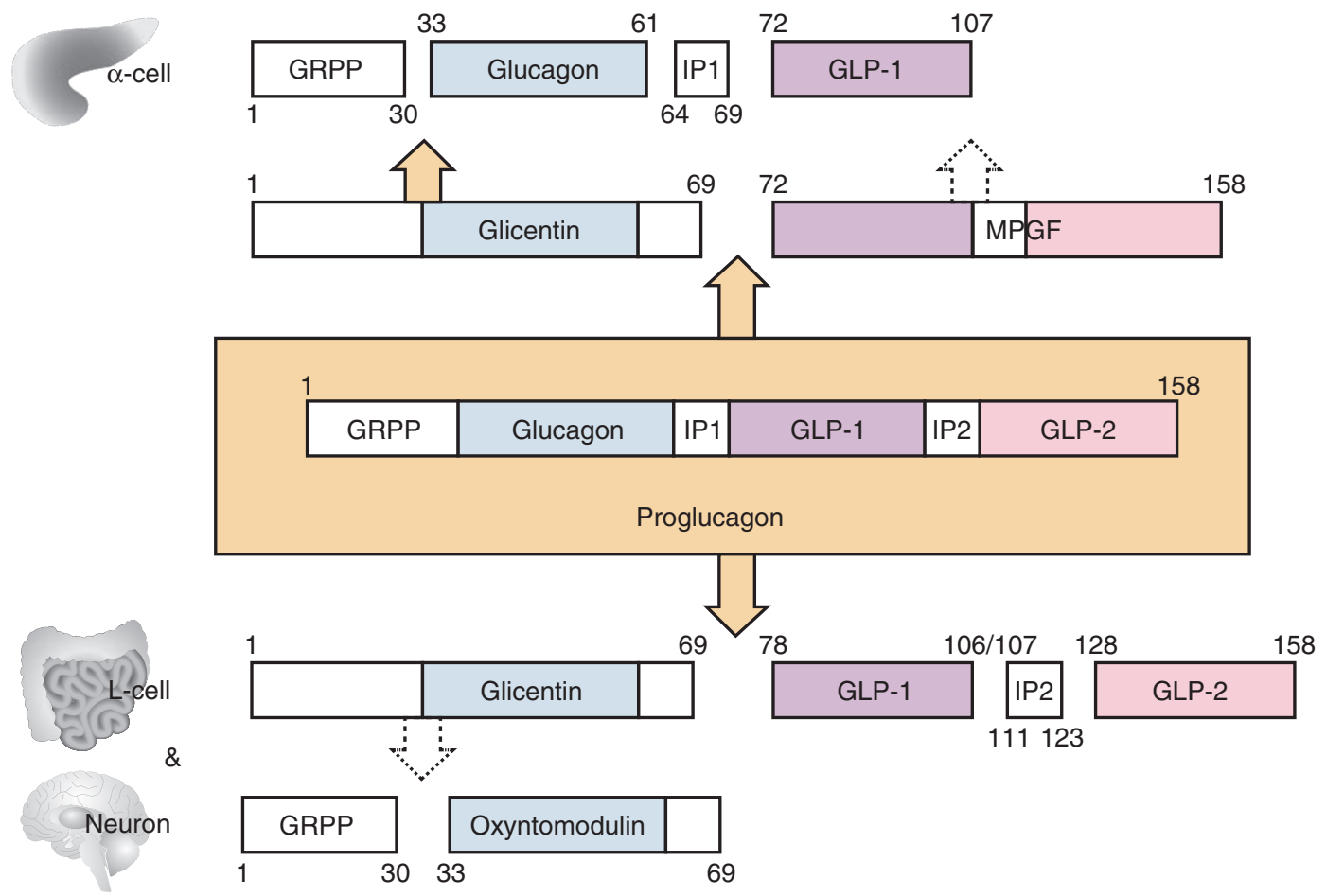

Figure 1 | Main products of proglucagon posttranslational processing. GLP-1, glucagon-like peptide 1; GLP-2, glucagonlike peptide 2; GRPP, glicentin-related pancreatic polypeptide; IP1, intervening peptide 1; MPGF, major proglucagon fragment. Partial processing is indicated by dashed arrows. Adapted with permission from reference. ${ }^{6}$

actions of GIP on cholinergic fibres of the vagus nerve. ${ }^{14}$ Gastrin-releasing peptide has been identified as a potent secretagogue of GLP-1 from the L cell. ${ }^{25,}{ }^{26}$ After direct secretion stimulated by nutrients, especially fats, on the $\mathrm{L}$ cells, other peptides and hormones that influence GLP-1 secretion have been identified, including intestinal somatostatin, gamma-aminobutyric acid, and $\alpha$ - and $\beta$ adrenergic agonists. ${ }^{14}$ Leptin, a cytokine derived from adipocytes, also has been implicated in GLP-1 secretion. $^{14}$

\section{Degradation}

After their release, GLP-1 and GLP-2 are quickly degraded through cleavage of $\mathrm{N}$-terminal histidine and alanine by the ubiquitously expressed proteolytic enzyme dipeptidyl peptidase-IV (DPP-IV), resulting in the generation of biologically inactive GLP-1(9-36 amide) or GLP1(9-37) and GLP-2(3-33) respectively. ${ }^{27-30}$ GLP-1 is very susceptible to degradation via DPP-IV. ${ }^{27}$ Porcine studies have shown that a significant amount of GLP-1 leaves the intestines as inactive metabolite and non-amidated GLP$1(9-37),{ }^{31,32}$ such that $<25 \%$ of GLP-1 is believed to leave in an intact, active form. ${ }^{2}$ In human plasma, DPPIV activity results in an apparent half-life for intact GLP-
1 of $1-2$ min. $^{33}$ In contrast, GLP-2 is less susceptible to DPP-IV degradation, with all of the newly released GLP2 leaving the gut as the active form. ${ }^{27},{ }^{34}$ Intact GLP-2 has an apparent plasma half-life of $7 \mathrm{~min}$ in humans. ${ }^{35}$ Once in the plasma, the kidney provides the major route of clearance for both GLP-1 and GLP-2. ${ }^{36}$ Patients with chronic renal insufficiency have elevated levels of circulating GLP-1 compared with healthy subjects. ${ }^{37}$

\section{Prolongation of half-life}

To date, there are two different successful strategies in mitigating the issue with the short half-life of GLP-1 and GLP-2. The first is the use of mimetics of GLP-1 and GLP-2 that are resistant to inactivation by DPP-IV, thus prolonging and enhancing the effect of the hormone. Liraglutide (Victoza; Novo Nordisk) and teduglutide (GATTEX; NPS Pharmaceuticals, Bedminster, NJ, USA) are examples. Liraglutide is a GLP-1 analogue with an additional 16-carbon fatty acid and a small amino acidbased spacer that confers reversible binding of the agonist to albumin and increases resistance to DPP-IV activity, providing liraglutide with a half-life of approximately $13 \mathrm{~h}$. Teduglutide was developed by replacing alanine with glycine in position 2 of GLP-2, providing a 


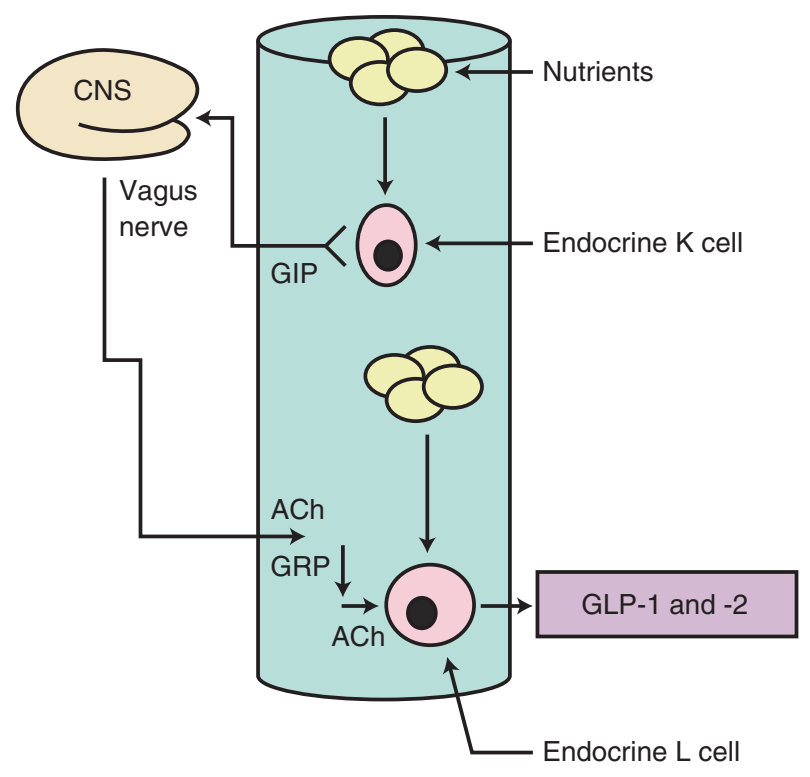

Figure 2 | Direct and indirect effects of nutrients on secretion of GLP-1 and GLP-2. Ach, acetylcholine; CNS, central nervous system; GIP, glucose-dependent insulinotropic polypeptide; GLP-1, glucagon-like peptide 1; GLP-2, glucagon-like peptide 2. Entry of nutrients into the proximal small intestines initiates an early peak of secretion mediated through the vagus nerve. The afferent component of this neural loop is activated by ingested nutrients either directly or through release of an enteroendocrine hormone, such as GIP from the K cells. Vagal efferent fibres then stimulate the distal $L$ cells through a pathway that likely involves both ACh and GRP within the enteric nervous system. Further aboral movement of the nutrients down the lumen of the small intestine stimulates a second, later peak of GLP-1 and GLP-2 secretion through direct effects on L cells. Adapted with permission from reference. ${ }^{24}$

molecule with a half-life of 3-4 h. ${ }^{38}$ The second strategy involves inhibition of DPP-IV, prolonging the effect of endogenously secreted GLP-1 and GLP-2 with drugs like vildagliptin (Galvus; Novartis Pharmaceuticals, East Hanover, NJ, USA) and sitagliptin (Januvia; Merck \& Co., Whitehouse Station, NJ, USA).

\section{Role of GLP receptors}

Like glucagon, the actions of GLP-1 and GLP-2 are mediated through class 2 G-protein-coupled receptors. These receptors are distinct and specific for either GLP-1 or GLP2 , despite sharing the conserved properties of their class. ${ }^{39}$

GLP-1 receptor (GLP-1R). In the early 1990s, complementary DNAs (cDNA) of rat and human GLP-1R were cloned and sequenced from their respective pancreatic islet cDNA libraries. The human GLP-1R gene was found to span $40 \mathrm{~kb}$; it has been mapped to chromosome 6 and band p21.1 and consists of at least 7 exons. ${ }^{40}$ GLP-1R typically couples via a stimulatory $G$ protein to adenylate cyclase. $^{40,41}$

The GLP-1R is expressed in the pancreatic islets, brain, enteric nervous tissue, heart, kidney, small and large intestine and stomach. ${ }^{42-47}$ In the brain, the GLP$1 \mathrm{R}$ has been identified in regions that control feeding behaviour, such as the brainstem and the hypothalamus. ${ }^{44,}{ }^{48}$ It has also been found in the nodose ganglion of the vagus nerve and has presynaptic peripheral action in the small and large intestine in addition to direct nonneural effects in peripheral tissue. ${ }^{40,}{ }^{46-50}$ This suggests that GLP-1 affects human physiology through interaction with centres in the brain, afferent neural pathways and peripheral direct and neural mechanisms.

GLP-2 receptor (GLP-2R). The GLP-2R has been cloned from the stomach, small bowel and hypothalamus cDNA libraries. $^{39,51}$ The GLP-2R gene has been localised to human chromosome 17p13.3. ${ }^{39}$ Unlike the widely expressed GLP-1R, GLP-2R expression is restricted to the GI tract and the CNS, with limited expression in the lung, cervix and vagal afferents, ${ }^{39,51,52}$ although cardiac expression in rats has been reported recently. ${ }^{53}$ Multiple experimental approaches have localised the GLP-2R to regions within the rodent CNS, including the hippocampus, hypothalamus and nucleus of the solitary tract in the mouse. ${ }^{54,}{ }^{55}$ It is currently unknown whether analogous expression of GLP-2R is found in the brain of nonrodent species.

The exact cellular localisation of the GLP-2R in the gut in early studies had been a source of controversy. GLP-2R has been reported in enteroendocrine cells, ${ }^{51}$ enteric neurons ${ }^{56}$ and subepithelial myofibroblasts. ${ }^{57}$ However, in the murine GI tract, the GLP-2R is expressed exclusively in neurons and myofibroblasts and is not present at the mucosal level. ${ }^{56}$ It is now generally accepted that the above three cell types express GLP-2R in the intestine.

In mice, GLP-2R-mRNA has been demonstrated with high levels of expression in the bowel, ${ }^{51}$ and recently the GLP-2R protein has been demonstrated throughout the GI tract, with higher expression in the gastric fundus and colon. ${ }^{58}$ The relatively high prevalence of the GLP$2 \mathrm{R}$ in the gut might explain why, to date, GLP-2-mediated effects have been observed almost exclusively in the GI tract. ${ }^{59}$ GLP-1R expression appears to be more widespread than GLP-2R expression. 


\section{P. Janssen et al.}

Because the GLP-2R is expressed in the subepithelial myofibroblasts ${ }^{57}$ and in the enteric nervous system as well as human enteroendocrine cells, and not on the crypt cells or enterocytes themselves, it has been proposed that the GLP-2 exerts its actions on the mucosa via intermediate effectors derived from GLP-2R-expressing cells. ${ }^{51}$ Different studies have provided mechanistic data illustrating several pathways of GLP-2 action and suggest that keratinocyte growth factor and endothelial nitric oxide (NO) synthase are mediators involved in GLP-2-induced colonic growth and intestinal blood flow $^{57,60,61}$ and that insulin-like growth factors, ${ }^{62-64}$ the ErbB network, ${ }^{65,66}$ and vasoactive intestinal peptide $(\mathrm{VIP})^{67}$ are the key mediators in the trophic actions of GLP-2. Neural VIP, NO and reduction of the acetylcholine release from enteric nerves have been reported to be involved in the inhibitory motor effects induced by GLP2 in different regions of the mouse GI tract. ${ }^{58,68,69}$ Determining how GLP-2 produces its biological effects, which mediators are involved and how these mediators interact is an area of intense research. ${ }^{70,71}$

\section{Functional ontogeny}

The ontogeny of the proglucagon-derived axis is incompletely understood, although there is evidence from both animal and human models that it plays an important role in intestinal development. The GLP-1/GLP-2 receptor axis is expressed and functional in the developing intestine of rats. An investigation in foetal and neonatal rat gut showed that comparatively high levels of GLP-2R messenger RNA transcripts in the foetal and neonatal intestine declined to adult levels by postnatal day $21{ }^{72}$

Studies in infants with intestinal dysfunction due to resection show that GLP-2 levels are correlated with residual intestinal length and nutrient absorptive capacity; high postprandial GLP-2 levels appeared to be predictive of the ability to wean the infants from total parenteral nutrition (TPN). ${ }^{73}$ Studies in premature human neonates show that they have significantly higher fasting levels of both GLP-1 and GLP-2 compared with either older infants or adults. Feeding increases these levels further, ${ }^{74}$ consistent with a role for the proglucagon peptides in normal human intestinal development and function.

\section{GLUCAGON-LIKE PEPTIDE 1}

GLP-1 is a 31-amino acid peptide whose sequence is highly conserved among mammals and maintains some conserved amino acids in common with GLP-2 and glucagon (Figure 3). ${ }^{75,76}$ It circulates in two equally potent

Glucagon HSQGTFTSDYSKYLDSRRAQDFVQWLMNT

GLP-1

HAEGTFTSDVSSYLEGQAAKEF I AWL V KGRG

GLP-2

HADGSFSDEMNT ILDNLAARDF I NWL I QTK I TD

Figure 3 | Similarities and differences between amino acid sequences of glucagon, GLP-1 and GLP-2. A, alanine; C, cysteine; $D$, aspartic acid; $E$, glutamic acid; F, phenylalanine; G, glycine; GLP-1, glucagon-like peptide 1; GLP-2, glucagon-like peptide 2; $\mathrm{H}$, histidine; I, isoleucine; $K$, lysine; L, leucine; $M$, methionine; $N$, asparagine; $P$, proline; $Q$, gutamine; $R$, arginine; $S$, serine; $T$, threonine; $V$, valine; $W$, tryptophan; $Y$, tyrosine. Amino acids common to all three peptides are shown in bold. Amino acids common to glucagon and GLP-1 are shown in green; those common to GLP-1 and GLP-2 are shown in blue; those common to glucagon and GLP-2 are shown in red. Adapted with permission from reference. ${ }^{75}$

forms, GLP-1(7-36 amide) and GLP-1(7-37), although the amidated form is more abundant after eating. ${ }^{77,78}$

\section{Physiological effects}

GLP-1 has multiple actions (Figure 4), of which one of the most important is its activity as an incretin hormone, which regulates blood glucose levels by amplifying postprandial insulin synthesis and secretion. ${ }^{79}$ It also stimulates somatostatin release and inhibits glucagon secretion. ${ }^{80}$

GLP-1 is also known as an anorexigenic peptide, which increases satiety. In animal models, GLP-1 inhibited food and drink intake upon intracerebroventricular injection via direct modulation of the brain centres that control food intake, such as the nucleus tractus solitarii. ${ }^{48,81}$ Following intravenous (IV) infusion in humans, GLP-1 inhibited food and fluid intake in normal and obese individuals ${ }^{82-86}$; this effect appeared to be mediated through its incretin properties and/or inhibition of gastric emptying. ${ }^{82,83,85}$

GLP-1 also affects other aspects of GI physiology. In addition to slowing gastric emptying in both healthy and obese individuals, ${ }^{87}{ }^{88}$ GLP-1 is a mediator of the ileal brake, ${ }^{89}$ reduces gut motility ${ }^{47,50,90-92}$ and inhibits gastric acid secretion. ${ }^{50,85,93-96}$ The rate of gastric emptying is negatively correlated with circulating levels of GLP-1 and is positively correlated with the normalisation of glycaemia. ${ }^{20,97,98}$

GLP-1 increases gastric accommodation. ${ }^{99-101}$ In fasted healthy volunteers, peripherally administered 


\section{Pancreas}

$\uparrow$ Insulin synthesis and secretion

$\downarrow$ Glucagon secretion

$\uparrow$ Somatostatin secretion

$\uparrow$ Expression of genes that modify $\beta$-cell function

$\uparrow \beta$-cell proliteration and neogenesis

$\uparrow \beta$-cell survival

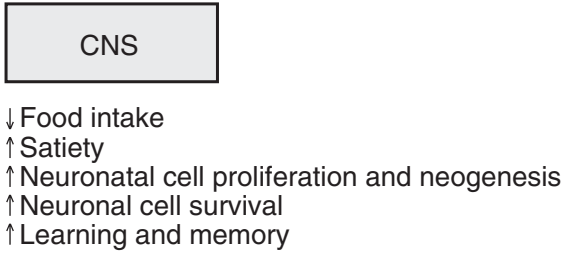

Neuronal cell surviva

$\uparrow$ Learning and memory

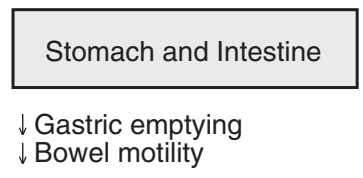

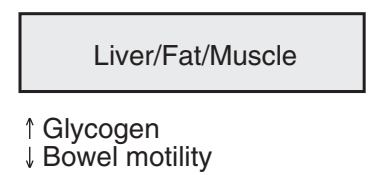

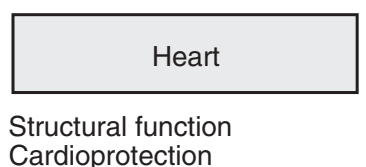

Figure 4 | Documented effects of GLP-1 and analogues. CNS, central nervous system; GLP-1, glucagon-like peptide 1. Adapted with permission from reference. ${ }^{1}$

synthetic GLP-1 dose-dependently increased fundic relaxation and compliance of the proximal stomach ${ }^{91}$ with a significant reduction of feeling of hunger. This may further support the concept that GLP-1 reduces food intake independent of a direct interaction with hypothalamic satiety centres. ${ }^{48,50,87}$

Direct gastric effects. The mechanism through which GLP-1 mediates inhibition of gastric emptying and gut motility is not fully understood but likely involves vagal nerve activation ${ }^{48,50,87}$ and direct actions on the gut wall. ${ }^{58,94}$ Some studies have documented that the inhibitory effect on gastric emptying is lost in rats after vagal deafferentation ${ }^{50}$ and in humans after truncal vagotomy. ${ }^{87}$ Although in vitro studies have shown that in human or rat gastric muscular strips GLP-1 did not affect the smooth muscle contractility of the proximal stomach (fundus and corpus), ${ }^{95,} 102$ more recent analysis has demonstrated the ability of GLP-1 to directly relax the mouse stomach, in particular the antral region, in which the GLP-1R is more clearly expressed. ${ }^{94}$

Enteric neuronal effects. The peripheral direct actions could be more important than previously appreciated. In support of a role of the enteric nervous system in mediating GLP-1 action, immunohistochemical and functional evidence obtained in mouse small and large intestines has demonstrated GLP-1R expression in the enteric neurons, some of which are coexpressing NO synthase or choline acetyl transferase, ${ }^{58}$ and the peptide's ability to modulate negatively, through NO release, the excitatory cholinergic neurotransmission. Therefore, GLP-1 inhibitory effects on
GI motility appear to be mediated by NO release from enteric neurons. $^{58,88,92,95,100}$

$\beta$-cell effects. GLP-1 is also able to modulate pancreatic $\beta$-cell proliferation, and there is evidence that GLP-1 increases pancreatic $\beta$-cell mass. This effect may occur by enhancing proliferation and inhibiting apoptosis of $\beta$ cells and by stimulating differentiation of stem cells in the ductal epithelium. ${ }^{103,104}$ Similar proliferative, antiapoptotic and neogenic effects have been found on neuronal cells. In experimental models of diabetes, GLP-1 expanded the $\beta$-cell mass, which is usually reduced; increased resistance to $\beta$-cell injury and reduced elevated glucose in the fasting and fed state. ${ }^{105-107}$ This feature, in combination with the control of systemic glucose distribution during hyperglycaemia, thereby increasing hepatic glycogen storage, has marked GLP-1 as a potential agent for the treatment of diabetes. ${ }^{108}$

\section{Clinical use of GLP-1}

Because of its incretin property, the potential benefits of GLP-1 in the treatment of type 2 diabetes have been amply demonstrated. ${ }^{109-111}$ In humans, the half-life of biologically active native GLP-1 in circulation is $2 \mathrm{~min}$, requiring continuous infusion or multiple injections to achieve clinical effect. ${ }^{33}$ To overcome this limitation, DPP-IV inhibitors and DPP-IV-resistant analogues or agonists of GLP-1R have been investigated. ${ }^{112,} 113$

Several DPP-IV inhibitors (incretin enhancers) have been developed and four have been approved for use in Europe (saxagliptin, sitagliptin, vildagliptin and linagliptin). Saxagliptin, sitagliptin and linagliptin are also available 


\section{P. Janssen et al.}

in the United States. These agents typically reduce DPPIV activity by more than $80 \%$, resulting in postprandial increases in GLP-1 and thereby increasing the incretin activities of GLP-1. ${ }^{114}$ However, the safety of long-term inhibition of such a ubiquitous enzyme with numerous substrates remains a theoretical concern. ${ }^{114}$

Two GLP-1 analogues [incretin mimetics; i.e. exenatide (Byetta; Amylin Pharmaceuticals, San Diego, CA, USA) and liraglutide] are commercially available and are used in type 2 diabetes treatment, all of which have activities similar to native GLP-1. ${ }^{115}, 116$

The incretin effects of the analogues are similar to those of GLP-1, including glucose-dependent stimulation of insulin, enhanced postprandial stimulation of insulin, regulation of glucose secretion in hypoglycaemia and hyperglycaemia, increased secretion of proinsulin, increase in the pancreatic islet $\beta$-cell mass, stimulation of differentiation of precursor cells into $\beta$ cells, inhibition of $\beta$ cell apoptosis, slowed gastric emptying, suppression of appetite, induction of satiety and weight loss. ${ }^{114,}$ 117-119 In addition, a recent study suggests that exenatide can directly inhibit intestinal synthesis of certain liproproteins independent of its satiety-promoting effects, suggesting that it may also act to lessen hyperlipidaemia in diabetic patients. ${ }^{120}$

In phase III trials involving patients with type 2 diabetes, both exenatide and liraglutide, alone or in combination with other antidiabetic agents, significantly reduced haemoglobin $A_{1 c}$ levels compared with the placebo or comparator groups (Figure 5). ${ }^{114}$ In the United States, exenatide and liraglutide are each indicated as an adjunct to diet and exercise to improve glycaemic control in adults with type 2 diabetes mellitus. ${ }^{121,122}$ A case series suggested the ability of exenatide to improve nutritional status and GI symptoms in patients with SBS, possibly through a slowing of gastric emptying and small bowel transit, allowing improved nutrient absorption. ${ }^{123}$ However, confirmation in a controlled study is lacking at present.

In clinical practice, GLP-1 analogues are applied primarily in the treatment of type 2 diabetes, where they are administered to improve glycaemic control in patients who are insufficiently controlled on oral antidiabetic agents, or in patients who are susceptible to hypoglycaemia. In addition, the weight loss associated with longer term use of GLP-1 analogues may also improve glycaemic control and convey additional metabolic benefits.

Safety and tolerability of GLP-1 and incretin mimetics Gastrointestinal adverse effects, especially nausea, are the most common adverse events with exenatide or
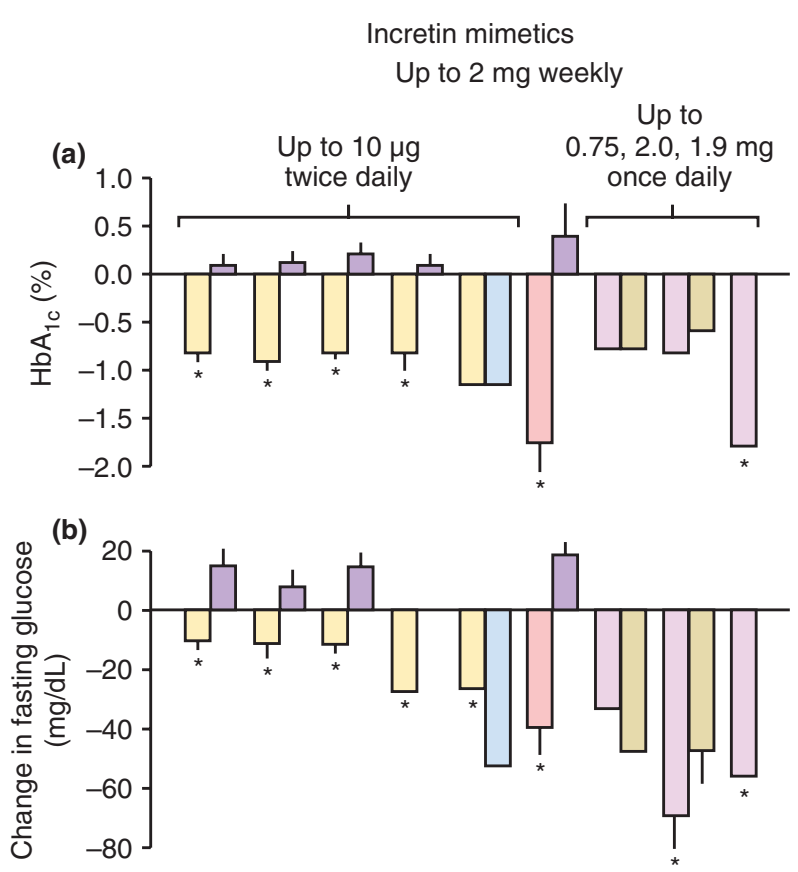

(c) Duration (weeks)

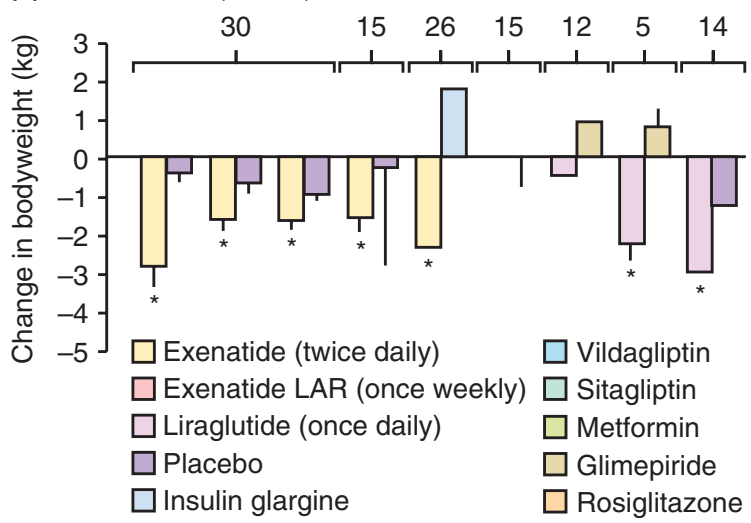

Figure 5 | Clinical effects of GLP-1 analogues on $\mathrm{HbA}_{1 \mathrm{c}}$ fasting glucose concentrations and body weight. GLP-1, glucagon-like peptide $1 ; \mathrm{HbA}_{1 \mathrm{c}}$, glycosylated haemoglobin. Results are from phase II or III studies on exanatide, exanatide LAR and liraglutide. Significant differences to placebo or respective comparator; if no comparator is shown, results are depicted as placebosubtracted differences. Bars are mean and SE. Adapted with permission from reference. ${ }^{114}$

liraglutide. ${ }^{115,} 116$ We speculate that the GLP-1-associated decrease in gastric emptying might be responsible for the nausea commonly seen with these agents.

GLP-1 analogues have been associated with several safety concerns ${ }^{116,124-129}$ (Table 1), especially the development of pancreatitis with exenatide and liraglutide. ${ }^{125}, 127,129$ This is of particular concern because the risk of pancreatitis is increased in individuals with type 2 
diabetes who are obese or treated with a sulfonylurea compared with the nondiabetic population. ${ }^{130}$ Furthermore, diabetes is associated with a risk for microvascular complications, and GLP-1R is expressed in the heart and in areas of the CNS that regulate cardiovascular function. ${ }^{131}$ Animal studies suggest that administration of GLP-1 may be cardioprotective in some circumstances. ${ }^{132,} 133$ Some positive effects of GLP-1 have been reported in patients with heart disease; GLP-1 improved endothelial dysfunction in type 2 diabetes patients with established coronary artery disease. ${ }^{134}$

\section{GLUCAGON-LIKE PEPTIDE 2}

GLP-2 is highly conserved across different mammalian species $^{135}$; both GLP-2(1-33) and its metabolite GLP-2(3-33) circulate in the plasma of fasting rats and humans. ${ }^{30,} 34$ GLP-2(3-33) is known to be a weak agonist for the GLP$2 \mathrm{R}$ in pharmacological concentrations but is also able to act as a competitive antagonist of the GLP-2R in rodents. ${ }^{136,137}$ Whether GLP-2(3-33) acts as a specific GLP-2R antagonist has not yet been defined, and the synthesis and use of GLP-2R antagonists would be useful to better identify the role of endogenous GLP-2.

\section{Physiological effects}

GLP-2 was first discovered as an intestinotrophic factor in $1996^{135}$; today, it is recognised as a hormone that influences multiple functions specifically in the GI tract. Unlike GLP-1, GLP-2 is not an incretin because of a limited effect on insulin, glucose homeostasis and glucagon. ${ }^{138}$ The main biological effects of GLP-2 are related to the regulation of energy absorption and maintenance of mucosal morphology, function and integrity of the intestine. ${ }^{135,}{ }^{139-141}$ However, in considering the actions of GLP-2, it is important to note that this peptide has

Table 1 | Safety issues with clinical use of GLP-1 analogues and GLP-2 analogue $e^{71,112,129,204,} 205$

\begin{tabular}{ll}
\hline GLP-1 Analogues & GLP-2 Analogue \\
\hline Pancreatitis & $\begin{array}{c}\text { Carcinogenesis } \\
\text { (theoretical)_in cancer } \\
\text { sensitised mouse models }\end{array}$ \\
$\begin{array}{l}\text { Hypoglycaemia when combined } \\
\text { with sulfonylurea }\end{array}$ \\
$\begin{array}{l}\text { Renal impairment (exenatide) } \\
\text { Hypersensitivity reactions- } \\
\text { anaphylaxis and angioedema } \\
\text { Thyroid C-cell tumours in animals }\end{array}$ \\
\hline \begin{tabular}{l} 
GLP, glucagon-like peptide. \\
\hline
\end{tabular}
\end{tabular}

been found to exhibit different actions in different species (i.e. rodents, pigs and humans), as noted in the following discussions.

Intestinotrophic effects. A key beneficial effect of GLP-2 on the gut is its ability to increase intestinal growth owing to the enhancement of crypt cell proliferation and inhibition of apoptosis, resulting in expansion of villus height. ${ }^{135,139,140}$ GLP-2 appears to act through intestinal IGF-I to induce intestinal growth and crypt cell proliferation (Figure 6). ${ }^{62}$ However, the mechanisms through which GLP-2 affects the epithelium in an IGF-I dependent manner have not been fully explained. Studies in murine intestinal subepithelial myofibroblasts suggest that the phosphatidylinositol 3 kinase/Akt pathway may be implicated in the stimulatory effects of GLP-2. ${ }^{142}$ These findings provide further evidence that IGF-I produced by intestinal subepithelial myofibroblast cells play a key role in the intestinotrophic effects of GLP-2.

A number of studies have demonstrated that exogenously administered GLP-2 is trophic for the small intestine and, to a lesser extent, the colon. ${ }^{57,135,141,143}$

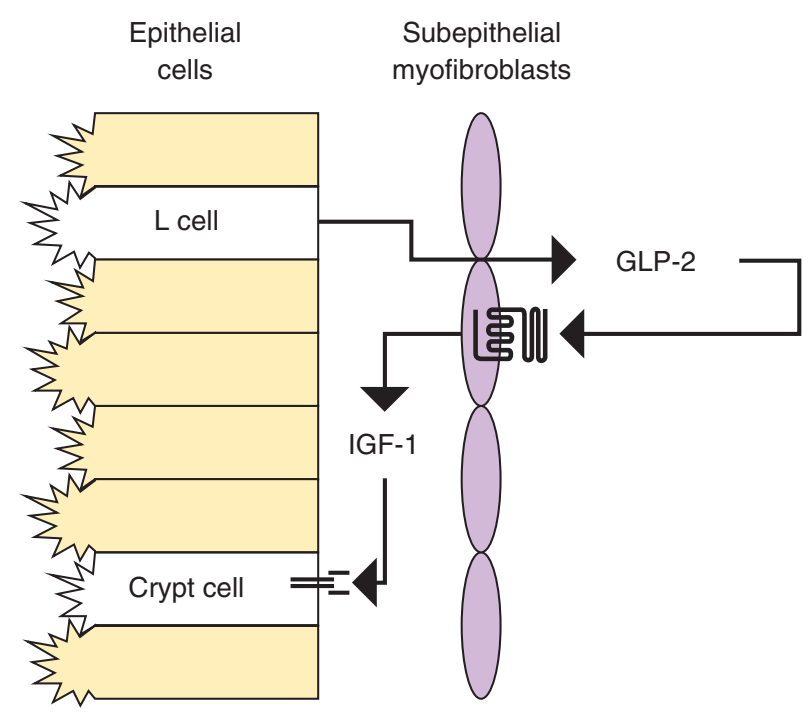

Figure 6 | Schematic representation of interactions between GLP-2 and IGF-I in the regulation of intestinal growth. After secretion by the intestinal $L$ cell into the circulation, GLP-2 activates the G protein coupled GLP2 receptor in the subepithelial myofibroblast cells, which subtend the epithelium as a syncytium. This leads to release of IGF-I, which then acts in a paracrine fashion on the tyrosine kinase IGF-IR expressed in the proliferative compartment of the crypt. ${ }^{62}$ Reprinted with permission from reference. ${ }^{62}$ 


\section{P. Janssen et al.}

Administration of exogenous GLP-2 to rats during and after massive bowel resection augmented adaptive growth in the residual small intestine without compromising endogenous GLP-2 production and secretion. ${ }^{144}$ Sustained administration of GLP-2 is necessary for intestinal adaptation, and benefits are lost when exogenous GLP-2 is discontinued. ${ }^{145,146}$

Endogenous GLP-2 also plays a role in the adaptive intestinal growth that occurs in rodents in response to oral refeeding after a period of nutrient deprivation, as shown by using GLP-2(3-33) or GLP-2R knockout mice. ${ }^{64,} 65,147$ The association between GLP-2 and intestinal growth/adaptation is most evident in a variety of pathologic conditions, including postresection intestinal adaptation, ${ }^{146,}{ }^{148}$ coeliac disease, ${ }^{149}$ parenteral nutritioninduced intestinal atrophy ${ }^{150}$ and IBD. ${ }^{151}$

Evidence that GLP-2 could induce an adaptive response alone, without endogenous enteral nutrients, was provided by a study carried out in parentally fed rats with SBS. ${ }^{152}$ In this study, rats given TPN plus GLP-2 treatment demonstrated significantly greater changes on measures of intestinal adaptation, including increases in bowel weight, villus height, intestinal mucosal surface area and crypt cell proliferation and reduced intestinal permeability and body weight loss, compared with resected animals given TPN alone. ${ }^{152}$

Similar trophic and functional responses to exogenous GLP-2 administration are seen in adult patients in whom the terminal ileum and colon have been resected. ${ }^{153,154}$ Adaptive responses are impaired in these individuals, who have limited meal-stimulated GLP-2 secretion due to removal of GLP-2-secreting L cells. Treatment with GLP-2 improves intestinal function and nutritional status in these patients. ${ }^{153-155}$ Among infants with nutrient malabsorption following intestinal surgery, postprandial GLP-2 levels correlated closely with length of remnant intestine and nutrient absorptive capacity. ${ }^{73}$

Mucosal integrity. GLP-2 maintains mucosal integrity by enhancing intestinal barrier function and decreasing transcellular and paracellular epithelial permeability. ${ }^{156}$ GLP-2 enhances barrier function within the setting of experimental food allergy, stress, or diabetes, reducing the uptake of antigen, the secretory response and the number of inflammatory cells. ${ }^{157-159}$ The effects of GLP-2 in increasing barrier function have been confirmed in non-obese diabetic and ob/ob obese murine models. ${ }^{159,} 160$ Administration of a prebiotic to ob/ob mice induces GLP-2-dependent upregulation of the tight junction proteins zonulin-1 and occludin. ${ }^{160}$
In addition, GLP-2 acts in pathophysiological states as an anti-inflammatory agent, reducing intestinal mucosal inflammatory cytokine production. ${ }^{67}$ This effect has been demonstrated in rat models of ileitis and colitis. GLP-2 treatment, given either immediately or after inflammation, significantly reduced body weight loss, mucosal inflammation indices, inflammatory cytokine levels and inducible NO synthase expression. These effects were likely mediated by activity of VIP, which is produced by the enteric nervous system and known to act as an antiinflammatory agent, because coadministration of a selective antagonist for VIP blocked the actions of GLP-2. Notably, the anti-inflammatory activity of GLP-2 was not associated with an increase in the rate of crypt cell proliferation. Instead, crypt cell proliferation and apoptosis within crypts in inflamed tissues were reduced. ${ }^{67}$ These findings support a potential additional neural mechanism of action for GLP-2, with therapeutic implications distinct from its role in promoting crypt cell proliferation.

Energy absorption. GLP-2 exerts numerous other actions within the GI tract to promote energy absorption. It increases the uptake of luminal nutrients, including sugars and lipids, ${ }^{161-164}$ by augmenting the activity and the expression of nutrient transporters ${ }^{4,165,166}$ and by enhancing the expression of different enzymes involved in digestion. ${ }^{164,} 167$ The major clinical benefit shown to date in adult patients is an increase in fluid and electrolyte absorption. ${ }^{153,}{ }^{154}$ In clinical studies, administration of GLP-2 or the degradation-resistant analogue teduglutide has been shown to slightly improve intestinal absorption, as indicated by increases in faecal wet weight (i.e. the measure of fluids and faeces excreted in bowel or ostomy output) and other indices of nutritional status (i.e. absorption of energy, macronutrients and electrolytes) in patients with SBS, even though differences were small and many did not achieve statistical significance. $^{153,154}$

GLP-2 also increases mesenteric blood flow, thus providing another mechanism to facilitate digestion and absorption of nutrients. ${ }^{60,61,168,169}$ GLP-2 has also been shown to inhibit gastric acid hypersecretion ${ }^{170}$ and intestinal chloride secretion. ${ }^{136}$

Gastric motility. The effects of GLP-2 on GI motility remain controversial. In animal models, GLP-2 has been demonstrated to reduce antral motility in pigs $^{171}$ and decrease gastric fundic tone in mice, leading to an increase of stomach capacity. ${ }^{68}$ Results regarding the 
ability of GLP-2 to suppress gastric motility in humans are conflicting, with GLP-2 either having no influence $^{163,172}$ or slowing gastric emptying. ${ }^{153,}{ }^{173}$ The discrepancies in results may be due to the differences in methodologies used to assess emptying or due to the type of test meal administered (low-calorie liquid meal vs. high-calorie solid meal). The effects of GLP-2 on gastric emptying and fundus tone indicate that GLP-2 could influence feeding behaviour. ${ }^{174}$ However, it is noted that the satiety effect is much more potent with GLP-1.

In mice, GLP-2 inhibits intestinal transit in vivo, ${ }^{175}$ and it reduces spontaneous or electrically evoked cholinergic contractions of the small and large intestine in $v i$ tro. ${ }^{58,69}$ The peptide modulation of GI motility may be due to CNS mechanisms, ${ }^{171}$ but involvement of the enteric nervous system also has been clearly shown through in vitro studies. ${ }^{58,68,69}$

CNS mechanisms. GLP-2 may influence food intake also because intracerebroventricular administration of GLP-2 reduces food intake in rodents. ${ }^{54,174}$ In rats, the satiety response to GLP-2 appeared dependent on a certain tone of central GLP-1Rs because pharmacologic antagonism of GLP-1 receptors by prior administration of exendin(9-39) abolishes GLP-2-induced anorexia. ${ }^{174}$ On the contrary, studies in mice have pointed to the opposite, finding that blocking central GLP-1Rs with exendin-9 increased GLP-2-induced anorexia. ${ }^{54}$

Further studies focusing on the role of central GLP$2 \mathrm{Rs}$ in appetite regulation are clearly needed. To date, studies in humans have not demonstrated a decrease in food intake after peripheral GLP-2 administration, ${ }^{172,} 176$ even if recent data have shown that intraperitoneal injections of GLP-2 reduces food intake in mice, suggesting a role for GLP-2 in the short-term regulation of the ingestive behaviour. ${ }^{177}$ In addition, there is a distinct lack of literature on GLP-2R expression in the nonrodent brain.

CNS effects. Few studies have been conducted to elucidate the roles of GLP-2 in the CNS, and an in-depth understanding of the complex neurobiology of preproglucagon-derived peptides in general is lacking. ${ }^{178}$ Consistent with a general cytoprotective effect of GLP-2 within the GI mucosa, few studies have suggested that activation of GLP-2Rs can protect neurons from excitotoxic damage. $^{55,179,180}$ More specifically, GLP-2 has been reported to reduce glutamate-induced cell death in cultured hippocampal cells, ${ }^{55}$ enhance survival of primary rat enteric neurons, and to stimulate the proliferation of rat astrocytes. ${ }^{179-181}$ Antidepressant-like effects of GLP-2 that occur via monoamine pathways have also been noted in mice, but this has yet to be confirmed. ${ }^{182}$ There are no data available as to whether an analogous expression of GLP-2R is found in the brain of nonrodent species. In addition, the function of GLP-2R activation in the brain, if it exists at all, is as yet unclear.

\section{Clinical use of GLP-2}

To date, the management of SBS or other types of intestinal failure focuses primarily on supplementation of nutrients, fluid and electrolytes. This is often accomplished via IV therapy. In the most favourable cases, IV nutrition or fluids are only required transiently while intestinal adaptation takes place, which allows a return to oral feeding. In patients with insufficient adaptation, long-term parenteral nutrition, or in few selected and eligible patients, intestinal transplantation, are often the only options. Hence, a major unmet need exists for treating patients with intestinal failure.

There has been much interest in GLP-2 as a target for SBS-associated intestinal failure. Preclinical studies in animal models of SBS have shown beneficial effects of GLP-2, consisting of increased body weight, restored absorptive capacity of the bowel, improved adaptive growth of the residual bowel, increased villus and mucosal height and improved mucosal antioxidant capacity. ${ }^{183-185}$ Administration of GLP-2 improved nutrient absorption and nutritional status in SBS patients with colectomy, who have normal GLP-2 fasting levels but do not show a postprandial physiologic increase of the peptide. ${ }^{153}$ However, the clinical use of GLP-2 is limited by a short half-life in circulation (6-7 min); consequently, several DPP-IV-resistant GLP-2 analogues are in development, including teduglutide, ZP1848, ZP1846 and FE203799.

Moreover, exogenous GLP-2 analogues (teduglutide) or DDP-IV inhibitors that increase concentrations of endogenous GLP-2 may be beneficial in treating other gut-related diseases, such as mucosal damage resulting from radiation, chemotherapy and nonsteroidal antiinflammatory drug (NSAID) usage (Table 2)., 186-189 Although teduglutide may have therapeutic benefits at different stages of intestinal disease, the greatest therapeutic efficacy has been observed when the peptide is given before the induction of gut injury. ${ }^{186,} 187$ In mice with radiation-induced mucositis, for example, teduglutide increased intestinal weight, crypt size, villus height and crypt stem-cell survival when given before irradiation. ${ }^{186}$ However, in experimental murine NSAID-induced enteritis, teduglutide improved histological evidence of 


\section{P. Janssen et al.}

Table 2 | Physiological and therapeutic effects of GLP-2 and GLP-2 analogues in the setting of GI disease: preclinical studies

\begin{tabular}{|c|c|c|}
\hline Disease model & Species & Effect(s) \\
\hline \multirow[t]{2}{*}{ Total parenteral nutrition } & Rat & $\begin{array}{l}\text { Decreased villus shortening and mucosal thinning } \\
\text { Increased mucosal surface area and weight of bowel } \\
\text { Increased body weight } \\
\text { Increased barrier function }\end{array}$ \\
\hline & Piglet & $\begin{array}{l}\text { Decreased mucosal proteolysis and apoptosis } \\
\text { Increased bowel mass } \\
\text { Increased intestinal blood volume } \\
\text { Increased portal vein flow rate } \\
\text { Stimulated NOS production and activity } \\
\text { Maintenance of intestinal structure } \\
\text { Maintenance of digestive and absorptive capacities }\end{array}$ \\
\hline Acute necrotising pancreatitis & Rat & Decreased intestinal permeability \\
\hline Food allergy & Mouse & $\begin{array}{l}\text { Decreased uptake of antigen } \\
\text { Diminished hypersensitivity reaction in bowel }\end{array}$ \\
\hline Burn injury & Rat & $\begin{array}{l}\text { Reduced burn-induced loss of bowel mass } \\
\text { Decreased immunosuppression }\end{array}$ \\
\hline Irradiation & Mouse & Decreased apoptosis in small bowel \\
\hline \multicolumn{3}{|l|}{ Inflammatory bowel disease } \\
\hline - Dextran-induced colitis & Mouse & $\begin{array}{l}\text { Improved survival } \\
\text { Increased colon area } \\
\text { Decreased cytokine expression }\end{array}$ \\
\hline - NSAID-induced enteritis & Mouse & $\begin{array}{l}\text { Decreased lesion number } \\
\text { Decreased intestinal permeability } \\
\text { Reduced inflammatory response }\end{array}$ \\
\hline - Antigen-induced GI inflammation & Rat & $\begin{array}{l}\text { Reduced mucosal damage } \\
\text { Decreased expression of TNF- } \alpha \text { and IFN- } \gamma \\
\text { Decreased diarrhoea } \\
\text { Reduced inflammation }\end{array}$ \\
\hline - Chemotherapy-induced mucosal damage & Mouse & $\begin{array}{l}\text { Improved survival } \\
\text { Decreased weight loss } \\
\text { Reduced bacteraemia } \\
\text { Attenuated epithelial injury }\end{array}$ \\
\hline Stress & Mouse & Improved intestinal barrier function \\
\hline
\end{tabular}

GI, gastrointestinal; GLP-2, glucagon-like peptide 2; IFN- $\gamma$, interferon gamma; NSAID, nonsteroidal anti-inflammatory drugs; NOS, nitric oxide synthase; TNF- $\alpha$, tumour necrosis factor alpha.

Adapted with permission from reference. ${ }^{4}$

the disease with a decrease in neutrophil infiltration, whether administered before, concomitant with, or after indomethacin. ${ }^{187}$ Consistent with the general mucosal cytoprotective actions of the peptide, findings from a pilot study suggested the potential effectiveness of teduglutide for inducing remission and mucosal healing in patients with active moderate to severe Crohn's disease. ${ }^{190}$

Teduglutide [h(Gly-2)GLP-2, ALX-0600] substitutes glycine in place of alanine in the key second position of the peptide, resulting in resistance to DPP-IV degradation and a longer biological half-life. Teduglutide is currently in the late stages of clinical development by NPS Pharmaceuticals, ${ }^{154,}{ }^{191}$ and its first indication is expected to be as an orphan drug for treatment of SBS. In an open-label 21- day study in 16 patients with SBS, teduglutide doses ranging between 0.03 and $0.15 \mathrm{mg} / \mathrm{kg} / \mathrm{d}$ subcutaneous (SC) decreased faecal wet weight and faecal energy excretion and increased wet weight absorption, urine weight and urinary sodium excretion. ${ }^{154}$ These effects were reversed over a 3-week posttreatment follow-up period. The changes in excretion and absorption were associated with increased villus height, crypt depth and mitotic index in the jejunum, and no changes in these mucosal proliferation indices in the colon. In a pivotal phase III study, 83 SBS patients received placebo, teduglutide $0.05 \mathrm{mg} / \mathrm{kg} / \mathrm{d}$ or teduglutide $0.1 \mathrm{mg} / \mathrm{kg} / \mathrm{d}$ SC for 24 weeks. The 0.05 $\mathrm{mg} / \mathrm{kg} / \mathrm{d}$ group was superior to placebo in achieving a $>20 \%$ reduction in parenteral fluid volume need and in 
obtaining a graded response score (a response evaluation taking into account magnitude and duration of reductions in parenteral fluid need). ${ }^{191}$ Response of similar magnitude in the $0.1-\mathrm{mg} / \mathrm{kg} / \mathrm{d}$ group did not reach statistical significance, probably because of higher baseline values in this group. Oral fluid intake was significantly decreased in the $0.1-\mathrm{mg} / \mathrm{kg} / \mathrm{d}$ group, and statistically significant increases in body weight occurred in the two teduglutide dose groups compared with placebo. ${ }^{191}$

ZP1848 and ZP1846 are GLP-2 mimetics developed by Zealand Pharma to enhance intestinal repair and attenuate inflammation (Zealand Pharma A/S, Copenhagen, Denmark). More specifically, ZP1848 is a GLP-2R agonist that is currently in clinical development for the treatment of Crohn's disease. ${ }^{192}$ ZP1846 is a GLP-2 peptide analogue, modified by Zealand's proprietary SIP technology. Preclinical pharmacologic studies showed that ZP1846 consistently stimulated growth of the small intestinal mucosa in mice ${ }^{193}$ and decreased the incidence and severity of chemotherapy-induced diarrhoea in rats. ${ }^{194}$

FE 203799 is a GLP-2 analogue in the early stages of development by Ferring Pharmaceuticals (San Diego, CA, USA). In rats, it has a low clearance rate resulting in a long half-life when administered subcutaneously $\left(t_{1 / 2}=701 \mathrm{~min}\right){ }^{195}$

\section{Safety and tolerability of GLP-2 and GLP-2 analogues and agonists}

In human studies, GLP-2 and GLP-2 analogues and agonists have been generally well- tolerated, with the incidence of adverse effects similar to that of placebo-treated subjects. ${ }^{154,}{ }^{191}$ Because GLP-2Rs are found predominantly in the GI tract, ${ }^{39,51,52}$ to date GLP-2-associated GI adverse effects have been observed in clinical trials. ${ }^{154,}{ }^{191}$ In an interim report of an ongoing 2-year open-label study with teduglutide in 76 SBS patients with intestinal failure, treatment was well-tolerated, with the major adverse events being gastrointestinal (22\%, mainly abdominal pain, distension, nausea, vomiting). ${ }^{196}$ No neutralising antibodies have been reported in published clinical trials. ${ }^{154,191,} 196$

The potential for carcinogenesis or promoting the growth of subclinical malignancies is a concern with use of GLP-2 or its analogues. ${ }^{6}$ The proliferative actions of GLP-2 in the GI tract has been demonstrated to occur in a regulated manner in normal tissue. ${ }^{119}, 123,125$ Findings that GLP-2R mRNA is present in human intestinal carcinoid tumours suggest that GLP-2 has the potential to stimulate the proliferation of neoplastic tissue. ${ }^{6,51,197}$ However, there has been no evidence of dysplasia or malignancy reported with the use of GLP-2 in humans. ${ }^{191}$
Indeed, a recent report suggests that human colon cancer has less expression of GLP-2R protein than the surrounding noncancerous tissue. ${ }^{198}$ However, in preclinical models in which a known carcinogen was first used to induce a malignancy, GLP-2 may promote tumourigenesis. ${ }^{199-201}$ In studies in which a known GI carcinogen was given first to stimulate malignant changes, GLP-2 enhanced the growth of polyps and tumours; administration of a longacting GLP-2 analogue (Gly2-GLP-2) or GLP-2 itself promoted the growth of dimethylhydrazine-induced colonic polyps - tubular adenomas confined to the colonic mucosa-in mice. ${ }^{200}$ Although the neoplasms were not cancerous, malignant transformation may occur in time. ${ }^{6,200}$ Studies have shown that colon carcinogenesis in azoxymethane-treated mice was increased by chronic treatment with GLP-2, but decreased with a GLP-2R antagonist. ${ }^{199}$ The effects of GLP-2 administration was studied in human colon cancer cell lines stably transfected with the GLP-2 receptor and in nude mice harbouring xenografts of these tumour cells. ${ }^{201}$ In colon cancer cell lines, GLP-2 administration did not attenuate cytotoxicity induced by chemotherapy, indomethacin, LY294002 or cycloheximide. Daily administration of GLP-2 did not alter tumour cell growth in the nude mice. ${ }^{201}$ In APC (Min/+) mice, daily administration of GLP-2 increased growth of normal gut mucosa, but did not increase the occurrence or size of colonic polyps. ${ }^{201}$

A recent report documented an increase in dysplasia with GLP-2 in two novel models of inflammation-associated colon cancer. In rats fed the carcinogen 2-Amino-1methyl-6-phenylimidazo[4,5-b]pyridine and a high-fat diet, 2 of 9 (22\%) rats receiving hGly ${ }^{2}$-GLP-2 developed intestinal cancer compared with 0 of $7(0 \%)$ control rats. In the other set of experiments, mice with chronic dextran sodium-sulphate induced colitis were administered azoxymethane to promote development of colon cancer. Among mice that received control injections, 56\% exhibited high-grade dysplasia or colon cancer compared with $64 \%$ of mice that received hGly ${ }^{2}$-GLP-2 and $46 \%$ of mice that received a GLP-2 antagonist. ${ }^{202}$ Studies in mice with conditional deletion of the intestinal growth factor 1receptor (IGF-1R) indicated that the proliferative response and intestinal epithelial adaptation seen with GLP-2 were dependent on the presence of the IGF-1R. GLP-2 induced crypt-cell proliferation and growth of the crypt-villus axis were reduced in the IGF-1-deficient mice compared with control mice. ${ }^{203}$

Although there have been no safety signals of malignancy in the clinical trials for teduglutide, ${ }^{191}$ it remains unclear what impact such analogues will have in the long 


\section{P. Janssen et al.}

term. Close vigilance may be prudent in patients receiving GLP-2 and GLP-2 analogues and agonists until more is known.

\section{SUMMARY}

Although derived from the same proglucagon, GLP-1 and GLP-2 have distinctly different biological activity profiles. GLP-1, an incretin, has many actions in various tissues, the most important being its role as a regulator of blood glucose levels by amplifying postprandial insulin secretion. Furthermore, it has proliferative, cytoprotective and neogenic effects on pancreatic $\beta$ cells and neuronal cells, regulating glucagon secretion and increasing pancreatic $\beta$-cell mass. GLP-1 also helps to ensure efficient assimilation of nutrients via effects on food intake and gastric emptying. In contrast, GLP-2 is an intestinotrophic hormone, regulating energy absorption via effects on nutrient intake, nutrient absorption and mucosal permeability. A main beneficial effect of GLP-2 on the gut is its ability to increase intestinal growth because of the enhancement of crypt cell proliferation and inhibition of apoptosis, resulting in expansion of villus height. GLP-2 analogues have been shown to increase fluid and electrolyte absorption in adult patients with intestinal disorders affecting mucosal absorption. These different and distinct biological actions of GLP-1 and GLP-2 have broad potential implications in the treatment of diabetes and GI disease respectively.

\section{ACKNOWLEDGEMENTS}

Declaration of personal interests: P. Janssen is currently employed by Shire Pharmaceuticals. However, this review originated and was written while P. Janssen was still employed by the University of Leuven. F. Mulé has received research funding from Ministero dell'Istruzione, dell'Università, e della Ricerca (MIUR - PRIN), Italy. J. Tack has served as a speaker, a consultant and an advisory board member for Addex Pharmaceuticals, Abbott, Alfa Wasserman, Almirall, Astellas, AstraZeneca, Danone, Forrest, Given, GlaxoSmithKline, Ipsen, Ironwood, Menarini, Norgine, Novartis, NPS Pharmaceuticals, Ocera, Ono Pharmaceuticals, Shire, Smartpill, Sucampo, Takeda, Theravance, Tranzyme, Xenoport and Zeria. Declaration of funding interests: The preparation of this article was funded by NPS Pharmaceuticals. Writing support was provided under the direction of the authors by Karin McGlynn and Noelle Schmidt who are employees of BRIOMed and received funding from NPS Pharmaceuticals. Editorial assistance in formatting, proofreading, copyediting and fact checking was provided by Tracy Bunting-Early, $\mathrm{PhD}$, a contractor for Complete Healthcare Communications, Inc. (CHC) and Maryann Travaglini, PharmD, an employee of CHC. Funding support for editorial assistance was also provided by NPS Pharmaceuticals. The authors maintained complete control over the content of the manuscript.

\section{REFERENCES}

1. Baggio LL, Drucker DJ. Clinical endocrinology and metabolism. Glucagon-like peptide-1 and glucagon-like peptide-2. Best Pract Res Clin Endocrinol Metab 2004; 18: 531-54.

2. Holst JJ. The physiology of glucagonlike peptide 1. Physiol Rev 2007; 87: 1409-39.

3. Drucker DJ. Enhancing incretin action for the treatment of type 2 diabetes. Diabetes Care 2003; 26: 2929 -40 .

4. Estall JL, Drucker DJ. Glucagon-like peptide-2. Annu Rev Nutr 2006; 26: 391-411.

5. Hornby PJ, Moore BA. The therapeutic potential of targeting the glucagon-like peptide- 2 receptor in gastrointestinal disease. Expert Opin Ther Targets 2011; 15: 637-46.

6. Wallis K, Walters JR, Forbes A. Review article: glucagon-like peptide 2 -current applications and future directions. Aliment Pharmacol Ther 2007; 25: 365-72.

7. Drucker DJ, Asa S. Glucagon gene expression in vertebrate brain. J Biol Chem 1988; 263: 13475-8.

8. Drucker DJ, Brubaker PL. Proglucagon gene expression is regulated by a cyclic AMP-dependent pathway in rat intestine. Proc Natl Acad Sci U S A 1989; 86: 39537.

9. Holst JJ, Bersani M, Johnsen AH, Kofod H, Hartmann B, Orskov C. Proglucagon processing in porcine and human pancreas. J Biol Chem 1994; 269: 18827-33.

10. Rouille Y, Kantengwa S, Irminger JC, Halban PA. Role of the prohormone convertase PC3 in the processing of proglucagon to glucagon-like peptide 1. J Biol Chem 1997; 272: 32810-6.
11. Ugleholdt R, Zhu X, Deacon CF, Orskov C, Steiner DF, Holst JJ. Impaired intestinal proglucagon processing in mice lacking prohormone convertase 1 . Endocrinology 2004; 145: 1349-55.

12. Wideman RD, Yu IL, Webber TD, et al. Improving function and survival of pancreatic islets by endogenous production of glucagon-like peptide 1 (GLP-1). Proc Natl Acad Sci U S A 2006; 103: 13468-73.

13. Zhu X, Zhou A, Dey A, et al. Disruption of $\mathrm{PC} 1 / 3$ expression in mice causes dwarfism and multiple neuroendocrine peptide processing defects. Proc Natl Acad Sci U S A 2002; 99: 10293-8.

14. Lim GE, Brubaker PL. Glucagon-like peptide 1 secretion by the L cell. Diabetes 2006; 55(Suppl. 2): S70-7.

15. Orskov C, Holst JJ, Knuhtsen S, Baldissera FG, Poulsen SS, Nielsen 
OV. Glucagon-like peptides GLP-1 and GLP-2, predicted products of the glucagon gene, are secreted separately from pig small intestine but not pancreas. Endocrinology 1986; 119: 1467-75.

16. Brubaker PL. The glucagon-like peptides: pleiotropic regulators of nutrient homeostasis. Ann N Y Acad Sci 2006; 1070: 10-26.

17. Herrmann C, Goke R, Richter G, Fehmann HC, Arnold R, Goke B. Glucagon-like peptide-1 and glucosedependent insulin-releasing polypeptide plasma levels in response to nutrients. Digestion 1995; 56: $117-$ 26.

18. Reimann F, Ward PS, Gribble FM. Signaling mechanisms underlying the release of glucagon-like peptide-1. Diabetes 2006; 55(Suppl. 2): S78-85.

19. Xiao Q, Boushey RP, Drucker DJ, Brubaker PL. Secretion of the intestinotropic hormone glucagon-like peptide 2 is differentially regulated by nutrients in humans. Gastroenterology 1999; 117: 99-105.

20. Nauck MA, Kemmeries G, Holst JJ, Meier JJ. Rapid tachyphylaxis of the glucagon-like peptide 1-induced deceleration of gastric emptying in humans. Diabetes 2011; 60: 1561-5.

21. Cummings DE, Overduin J. Gastrointestinal regulation of food intake. J Clin Invest 2007; 117: 13-23.

22. Reimann F, Gribble FM. Glucosesensing in glucagon-like peptide-1 secreting cells. Diabetes 2002; 51: 2757-63.

23. Rocca AS, Brubaker PL. Role of the vagus nerve in mediating proximal nutrient-induced glucagon-like peptide-1 secretion. Endocrinology 1999; 140: 1687-94.

24. Anini Y, Brubaker PL. Muscarinic receptors control glucagon-like peptide 1 secretion by human endocrine L cells. Endocrinology 2003; 144: 3244-50.

25. Roberge JN, Gronau KA, Brubaker PL. Gastrin-releasing peptide is a novel mediator of proximal nutrientinduced proglucagon-derived peptide secretion from the distal gut. Endocrinology 1996; 137: 2383-8.

26. Brubaker PL. Regulation of intestinal proglucagon-derived peptide secretion by intestinal regulatory peptides. Endocrinology 1991; 128: 3175 -82 .

27. Deacon CF, Johnsen AH, Holst JJ. Degradation of glucagon-like peptide1 by human plasma in vitro yields an $\mathrm{N}$-terminally truncated peptide that is a major endogenous metabolite in vivo. J Clin Endocrinol Metab 1995; 80: $952-7$.
28. Kieffer TJ, McIntosh $\mathrm{CH}$, Pederson RA. Degradation of glucosedependent insulinotropic polypeptide and truncated glucagon-like peptide 1 in vitro and in vivo by dipeptidyl peptidase IV. Endocrinology 1995; 136: 3585-96.

29. Tavares W, Drucker DJ, Brubaker PL. Enzymatic- and renal-dependent catabolism of the intestinotropic hormone glucagon-like peptide-2 in rats. Am J Physiol Endocrinol Metab 2000; 278: E134-9.

30. Brubaker PL, Crivici A, Izzo A, Ehrlich P, Tsai CH, Drucker DJ. Circulating and tissue forms of the intestinal growth factor, glucagon-like peptide-2. Endocrinology 1997; 138: 4837-43.

31. Hansen L, Deacon CF, Orskov C, Holst JJ. Glucagon-like peptide-1-(736)amide is transformed to glucagonlike peptide-1-(9-36)amide by dipeptidyl peptidase IV in the capillaries supplying the L cells of the porcine intestine. Endocrinology 1999; 140: $5356-63$.

32. Hansen L, Hartmann B, Bisgaard T, Mineo H, Jorgensen PN, Holst JJ. Somatostatin restrains the secretion of glucagon-like peptide- 1 and -2 from isolated perfused porcine ileum. Am J Physiol Endocrinol Metab 2000; 278: E1010-8.

33. Deacon CF, Nauck MA, Toft-Nielsen M, Pridal L, Willms B, Holst JJ. Both subcutaneously and intravenously administered glucagon-like peptide I are rapidly degraded from the $\mathrm{NH} 2$ terminus in type II diabetic patients and in healthy subjects. Diabetes 1995; 44: 1126-31.

34. Drucker DJ, Shi Q, Crivici A, et al. Regulation of the biological activity of glucagon-like peptide 2 in vivo by dipeptidyl peptidase IV. Nat Biotechnol 1997; 15: 673-7.

35. Hartmann B, Harr MB, Jeppesen PB, et al. In vivo and in vitro degradation of glucagon-like peptide- 2 in humans. J Clin Endocrinol Metab 2000; 85: 2884-8.

36. Ruiz-Grande C, Pintado J, Alarcon C, Castilla C, Valverde I, Lopez-Novoa JM. Renal catabolism of human glucagon-like peptides 1 and 2. Can J Physiol Pharmacol 1990; 68: 156873.

37. Meier JJ, Nauck MA, Kranz D, et al. Secretion, degradation, and elimination of glucagon-like peptide 1 and gastric inhibitory polypeptide in patients with chronic renal insufficiency and healthy control subjects. Diabetes 2004; 53: 654-62.

38. Wallis K, Walters JR, Gabe S. Short bowel syndrome: the role of GLP-2 on improving outcome. Curr Opin Clin Nutr Metab Care 2009; 12: 52632.

39. Munroe DG, Gupta AK, Kooshesh F, et al. Prototypic G protein-coupled receptor for the intestinotrophic factor glucagon-like peptide 2. Proc Natl Acad Sci U S A 1999; 96: 1569 73.

40. Baggio LL, Drucker DJ. Biology of incretins: GLP-1 and GIP. Gastroenterology 2007; 132: 2131-57.

41. Wheeler MB, Lu M, Dillon JS, Leng $\mathrm{XH}$, Chen C, Boyd AE 3rd. Functional expression of the rat glucagon-like peptide-I receptor, evidence for coupling to both adenylyl cyclase and phospholipase-C. Endocrinology 1993; 133: 57-62.

42. Bullock BP, Heller RS, Habener JF. Tissue distribution of messenger ribonucleic acid encoding the rat glucagon-like peptide-1 receptor. Endocrinology 1996; 137: 2968-78.

43. Campos RV, Lee YC, Drucker DJ. Divergent tissue-specific and developmental expression of receptors for glucagon and glucagon-like peptide-1 in the mouse. Endocrinology 1994; 134: 2156-64.

44. Dunphy JL, Taylor RG, Fuller PJ. Tissue distribution of rat glucagon receptor and GLP-1 receptor gene expression. Mol Cell Endocrinol 1998; 141: $179-86$

45. Tornehave D, Kristensen P, Romer J, Knudsen LB, Heller RS. Expression of the GLP-1 receptor in mouse, rat, and human pancreas. $J$ Histochem Cytochem 2008; 56: 841-51.

46. Nakagawa A, Satake H, Nakabayashi $\mathrm{H}$, et al. Receptor gene expression of glucagon-like peptide-1, but not glucose-dependent insulinotropic polypeptide, in rat nodose ganglion cells. Auton Neurosci 2004; 110: 36 43.

47. Amato A, Cinci L, Rotondo A, et al. Peripheral motor action of glucagonlike peptide- 1 through enteric neuronal receptors. Neurogastroenterol Motil 2010; 22: 664-e203.

48. Goke R, Larsen PJ, Mikkelsen JD, Sheikh SP. Distribution of GLP-1 binding sites in the rat brain: evidence that exendin- 4 is a ligand of brain GLP-1 binding sites. Eur $J$ Neurosci 1995; 7: 2294-300.

49. Bucinskaite V, Tolessa T, Pedersen J, et al. Receptor-mediated activation of gastric vagal afferents by glucagonlike peptide-1 in the rat. Neurogastroenterol Motil 2009; 21 : 978-e78.

50. Imeryuz N, Yegen BC, Bozkurt A, Coskun T, Villanueva-Penacarrillo 


\section{P. Janssen et al.}

ML, Ulusoy NB. Glucagon-like peptide-1 inhibits gastric emptying via vagal afferent-mediated central mechanisms. Am J Physiol 1997; 273: G920-7.

51. Yusta B, Huang L, Munroe D, et al. Enteroendocrine localization of GLP2 receptor expression in humans and rodents. Gastroenterology 2000; 119: 744-55.

52. Nelson DW, Sharp JW, Brownfield MS, Raybould HE, Ney DM. Localization and activation of glucagon-like peptide- 2 receptors on vagal afferents in the rat. Endocrinology 2007; 148: 1954-62.

53. Angelone T, Filice E, Quintieri AM, et al. Receptor identification and physiological characterisation of glucagon-like peptide-2 in the rat heart. Nutr Metab Cardiovasc Dis 2012; 22: 486-94.

54. Lovshin J, Estall J, Yusta B, Brown TJ, Drucker DJ. Glucagon-like peptide (GLP)-2 action in the murine central nervous system is enhanced by elimination of GLP-1 receptor signaling. J Biol Chem 2001; 276: 21489-99.

55. Lovshin JA, Huang Q, Seaberg R, Brubaker PL, Drucker DJ. Extrahypothalamic expression of the glucagon-like peptide-2 receptor is coupled to reduction of glutamateinduced cell death in cultured hippocampal cells. Endocrinology 2004; 145: 3495-506.

56. Bjerknes $\mathrm{M}$, Cheng $\mathrm{H}$. Modulation of specific intestinal epithelial progenitors by enteric neurons. Proc Natl Acad Sci U S A 2001; 98: 12497502.

57. Orskov C, Hartmann B, Poulsen SS, Thulesen J, Hare KJ, Holst JJ. GLP-2 stimulates colonic growth via KGF, released by subepithelial myofibroblasts with GLP-2 receptors. Regul Pept 2005; 124: 105-12.

58. Amato A, Rotondo A, Cinci L, Baldassano S, Vannucchi MG, Mule F. Role of cholinergic neurons in the motor effects of glucagon-like peptide-2 in mouse colon. Am J Physiol Gastrointest Liver Physiol 2010; 299: G1038-44.

59. Sinclair EM, Drucker DJ. Proglucagon-derived peptides: mechanisms of action and therapeutic potential. Physiology (Bethesda) 2005; 20: $357-65$.

60. Guan X, Karpen HE, Stephens J, et al. GLP-2 receptor localizes to enteric neurons and endocrine cells expressing vasoactive peptides and mediates increased blood flow. Gastroenterology 2006; 130: $150-64$.
61. Guan X, Stoll B, Lu X, et al. GLP-2 mediated up-regulation of intestinal blood flow and glucose uptake is nitric oxide-dependent in TPN-fed piglets 1. Gastroenterology 2003; 125: 136-47.

62. Dube PE, Rowland KJ, Brubaker PL. Glucagon-like peptide-2 activates beta-catenin signaling in the mouse intestinal crypt: role of insulin-like growth factor-I. Endocrinology 2008; 149: 291-301.

63. Liu X, Murali SG, Holst JJ, Ney DM. Enteral nutrients potentiate the intestinotrophic action of glucagonlike peptide-2 in association with increased insulin-like growth factor-I responses in rats. Am J Physiol Regul Integr Comp Physiol 2008; 295: R1794 -802 .

64. Nelson DW, Murali SG, Liu X, Koopmann MC, Holst JJ, Ney DM. Insulin-like growth factor I and glucagon-like peptide- 2 responses to fasting followed by controlled or ad libitum refeeding in rats. Am J Physiol Regul Integr Comp Physiol 2008; 294: R1175-84.

65. Bahrami J, Yusta B, Drucker DJ. ErbB activity links the glucagon-like peptide- 2 receptor to refeedinginduced adaptation in the murine small bowel. Gastroenterology 2010; 138: 2447-56.

66. Yusta B, Holland D, Koehler JA, et al. ErbB signaling is required for the proliferative actions of GLP-2 in the murine gut. Gastroenterology 2009; 137: 986-96.

67. Sigalet DL, Wallace LE, Holst JJ, et al. Enteric neural pathways mediate the anti-inflammatory actions of glucagon-like peptide 2. Am J Physiol Gastrointest Liver Physiol 2007; 293: G211-21.

68. Amato A, Baldassano S, Serio R, Mule F. Glucagon-like peptide-2 relaxes mouse stomach through vasoactive intestinal peptide release. Am J Physiol Gastrointest Liver Physiol 2009; 296: G678-84.

69. Cinci L, Faussone-Pellegrini MS, Rotondo A, Mule F, Vannucchi MG. GLP-2 receptor expression in excitatory and inhibitory enteric neurons and its role in mouse duodenum contractility. Neurogastroenterol Motil 2011; 23: e383-92.

70. Dube PE, Brubaker PL. Frontiers in glucagon-like peptide-2: multiple actions, multiple mediators. Am J Physiol Endocrinol Metab 2007; 293: E460-5.

71. Rowland KJ, Brubaker PL. The "cryptic" mechanism of action of glucagon-like peptide-2. Am J Physiol
Gastrointest Liver Physiol 2011; 301: G1-8.

72. Lovshin J, Yusta B, Iliopoulos I, et al. Ontogeny of the glucagon-like peptide- 2 receptor axis in the developing rat intestine.

Endocrinology 2000; 141: 4194 201.

73. Sigalet DL, Martin G, Meddings J, Hartman B, Holst JJ. GLP-2 levels in infants with intestinal dysfunction. Pediatr Res 2004; 56: 371-6.

74. Amin H, Holst JJ, Hartmann B, Wallace L, Wright J, Sigalet DL. Functional ontogeny of the proglucagon-derived peptide axis in the premature human neonate. Pediatrics 2008; 121: e180-6.

75. Drucker DJ. Glucagon-like peptide 2. J Clin Endocrinol Metab 2001; 86: 1759-64

76. Orskov C, Bersani M, Johnsen AH, Hojrup P, Holst JJ. Complete sequences of glucagon-like peptide-1 from human and pig small intestine. $J$ Biol Chem 1989; 264: 12826-9.

77. Orskov C, Rabenhoj L, Wettergren A, Kofod H, Holst JJ. Tissue and plasma concentrations of amidated and glycine-extended glucagon-like peptide I in humans. Diabetes 1994; 43: 535-9.

78. Orskov C, Wettergren A, Holst JJ. Biological effects and metabolic rates of glucagonlike peptide-1 7-36 amide and glucagonlike peptide-1 7 37 in healthy subjects are indistinguishable. Diabetes 1993; 42: 658-61.

79. Fehmann HC, Habener JF. Insulinotropic hormone glucagon-like peptide-I(7-37) stimulation of proinsulin gene expression and proinsulin biosynthesis in insulinoma beta TC-1 cells. Endocrinology 1992; 130: 159-66.

80. Orskov C, Holst JJ, Nielsen OV. Effect of truncated glucagon-like peptide-1 [proglucagon-(78-107) amide] on endocrine secretion from pig pancreas, antrum, and nonantral stomach. Endocrinology 1988; 123: 2009-13

81. Tang-Christensen M, Larsen PJ, Goke $\mathrm{R}$, et al. Central administration of GLP-1-(7-36) amide inhibits food and water intake in rats. Am J Physiol 1996; 271: R848-56.

82. Flint A, Raben A, Astrup A, Holst JJ. Glucagon-like peptide 1 promotes satiety and suppresses energy intake in humans. J Clin Invest 1998; 101 : 515-20.

83. Gutzwiller JP, Goke B, Drewe J, et al. Glucagon-like peptide-1: a potent regulator of food intake in humans. Gut 1999; 44: 81-6. 
84. Gutzwiller JP, Tschopp S, Bock A, et al. Glucagon-like peptide 1 induces natriuresis in healthy subjects and in insulin-resistant obese men. J Clin Endocrinol Metab 2004; 89: 3055-61.

85. Naslund E, Gutniak M, Skogar S, Rossner S, Hellstrom PM. Glucagonlike peptide 1 increases the period of postprandial satiety and slows gastric emptying in obese men. Am J Clin Nutr 1998; 68: 525-30.

86. Verdich C, Flint A, Gutzwiller JP, et al. A meta-analysis of the effect of glucagon-like peptide-1 (7-36) amide on ad libitum energy intake in humans. J Clin Endocrinol Metab 2001; 86: 4382-9.

87. Wettergren A, Wojdemann M, Meisner S, Stadil F, Holst JJ. The inhibitory effect of glucagon-like peptide-1 (GLP-1) 7-36 amide on gastric acid secretion in humans depends on an intact vagal innervation. Gut 1997; 40: 597-601.

88. Daniel EE, Anvari M, Fox-Threlkeld JE, McDonald TJ. Local, exendin-(939)-insensitive, site of action of GLP1 in canine ileum. Am J Physiol Gastrointest Liver Physiol 2002; 283 . G595-602.

89. Giralt M, Vergara P. Glucagonlike peptide-1 (GLP-1) participation in ileal brake induced by intraluminal peptones in rat. Dig Dis Sci 1999; 44: 322-9.

90. Miki T, Minami K, Shinozaki H, et al. Distinct effects of glucosedependent insulinotropic polypeptide and glucagon-like peptide- 1 on insulin secretion and gut motility. Diabetes 2005; 54: 1056-63.

91. Schirra J, Wank U, Arnold R, Goke B, Katschinski M. Effects of glucagonlike peptide-1(7-36)amide on motility and sensation of the proximal stomach in humans. Gut 2002; 50: 341-8.

92. Tolessa T, Gutniak M, Holst JJ, Efendic S, Hellstrom PM. Inhibitory effect of glucagon-like peptide-1 on small bowel motility. Fasting but not fed motility inhibited via nitric oxide independently of insulin and somatostatin. J Clin Invest 1998; 102: 764-74.

93. Anvari M, Paterson CA, Daniel EE, McDonald TJ. Effects of GLP-1 on gastric emptying, antropyloric motility, and transpyloric flow in response to a nonnutrient liquid. Dig Dis Sci 1998; 43: 1133-40.

94. Rotondo A, Amato A, Lentini L, Baldassano S, Mule F. Glucagon-like peptide-1 relaxes gastric antrum through nitric oxide in mice. Peptides 2011; 32: 60-4.
95. Tolessa T, Gutniak M, Holst JJ, Efendic S, Hellstrom PM. Glucagonlike peptide-1 retards gastric emptying and small bowel transit in the rat: effect mediated through central or enteric nervous mechanisms. Dig Dis Sci 1998; 43: 2284-90.

96. Wettergren A, Wojdemann M, Holst JJ. Glucagon-like peptide-1 inhibits gastropancreatic function by inhibiting central parasympathetic outflow. Am J Physiol 1998; 275: G984-92.

97. Wishart JM, Horowitz M, Morris HA, Jones KL, Nauck MA. Relation between gastric emptying of glucose and plasma concentrations of glucagon-like peptide-1. Peptides 1998; 19: 1049-53.

98. Linnebjerg H, Park S, Kothare PA, et al. Effect of exenatide on gastric emptying and relationship to postprandial glycemia in type 2 diabetes. Regul Pept 2008; 151: 123-9.

99. Andrews CN, Bharucha AE, Camilleri $\mathrm{M}$, et al. Nitrergic contribution to gastric relaxation induced by glucagon-like peptide-1 (GLP-1) in healthy adults. Am J Physiol Gastrointest Liver Physiol 2007; 292: G1359-65.

100. Andrews CN, Bharucha AE, Camilleri $\mathrm{M}$, et al. Effects of glucagon-like peptide- 1 and sympathetic stimulation on gastric accommodation in humans. Neurogastroenterol Motil 2007; 19: 716-23.

101. Delgado-Aros S, Kim DY, Burton DD, et al. Effect of GLP-1 on gastric volume, emptying, maximum volume ingested, and postprandial symptoms in humans. Am J Physiol Gastrointest Liver Physiol 2002; 282: G424-31.

102. Naslund E, Bogefors J, Gryback P, et al. GLP-1 inhibits gastric emptying of water but does not influence plasma. Scand J Gastroenterol 2001; 36: 156-62.

103. Farilla L, Bulotta A, Hirshberg B, et al. Glucagon-like peptide 1 inhibits cell apoptosis and improves glucose responsiveness of freshly isolated human islets. Endocrinology 2003; 144: 5149-58.

104. Hui H, Wright C, Perfetti R. Glucagon-like peptide 1 induces differentiation of islet duodenal homeobox-1-positive pancreatic ductal cells into insulin-secreting cells. Diabetes 2001; 50: 785-96.

105. Kim JG, Baggio LL, Bridon DP, et al. Development and characterization of a glucagon-like peptide 1-albumin conjugate: the ability to activate the glucagon-like peptide 1 receptor in vivo. Diabetes 2003; 52: 751-9.

106. Sturis J, Gotfredsen CF, Romer J, et al. GLP-1 derivative liraglutide in rats with beta-cell deficiencies: influence of metabolic state on betacell mass dynamics. Br J Pharmacol 2003; 140: 123-32.

107. Xu G, Stoffers DA, Habener JF, Bonner-Weir S. Exendin-4 stimulates both beta-cell replication and neogenesis, resulting in increased beta-cell mass and improved glucose tolerance in diabetic rats. Diabetes 1999; 48: 2270-6.

108. Knauf C, Cani PD, Perrin C, et al. Brain glucagon-like peptide-1 increases insulin secretion and muscle insulin resistance to favor hepatic glycogen storage. J Clin Invest 2005; 115: 3554-63.

109. Li Y, Xu W, Tang L, Gong M, Zhang J. A novel GLP-1 analog exhibits potent utility in the treatment of type 2 diabetes with an extended half-life and efficient glucose clearance in vivo. Peptides 2011; 32: 1408-14.

110. Pinelli NR, Hurren KM. Efficacy and safety of long-acting glucagon-like peptide- 1 receptor agonists compared with exenatide twice daily and sitagliptin in type 2 diabetes mellitus: a systematic review and meta-analysis. Ann Pharmacother 2011; 45: 850-60.

111. Portha B, Tourrel-Cuzin C, Movassat J. Activation of the GLP-1 receptor signalling pathway: a relevant strategy to repair a deficient beta-cell mass. Exp Diabetes Res 2011; 2011: 376509.

112. Madsbad S, Kielgast U, Asmar M, Deacon CF, Torekov SS, Holst JJ. An overview of once-weekly glucagonlike peptide-1 receptor agonistsavailable efficacy and safety data and perspectives for the future. Diabetes Obes Metab 2011; 13: 394-407.

113. Tanaka T, Nangaku M, Nishiyama A. The role of incretins in salt-sensitive hypertension: the potential use of dipeptidyl peptidase-IV inhibitors. Curr Opin Nephrol Hypertens 2011; 20: $476-81$.

114. Drucker DJ, Nauck MA. The incretin system: glucagon-like peptide-1 receptor agonists and dipeptidyl peptidase- 4 inhibitors in type 2 diabetes. Lancet 2006; 368: 1696-705.

115. Kendall DM, Riddle MC, Rosenstock $\mathrm{J}$, et al. Effects of exenatide (exendin4) on glycemic control over 30 weeks in patients with type 2 diabetes treated with metformin and a sulfonylurea. Diabetes Care 2005; 28: 1083-91.

116. Zinman B, Gerich J, Buse JB, et al. Efficacy and safety of the human 


\section{P. Janssen et al.}

glucagon-like peptide- 1 analog liraglutide in combination with metformin and thiazolidinedione in patients with type 2 diabetes (LEAD4 Met+TZD). Diabetes Care 2009; 32: 1224-30.

117. Nielsen LL, Young AA, Parkes DG. Pharmacology of exenatide (synthetic exendin-4): a potential therapeutic for improved glycemic control of type 2 diabetes. Regul Pept 2004; 117: 77-88.

118. Peters KR. Liraglutide for the treatment of type 2 diabetes: a clinical update. Am J Ther 2011; doi:10.1097/ MJT.0b013e3182204c16 [Epub ahead of print].

119. Thong KY, Jose B, Sukumar N, et al. Safety, efficacy and tolerability of exenatide in combination with insulin in the Association of British Clinical Diabetologists nationwide exenatide audit*. Diabetes Obes Metab 2011; 13: 703-10.

120. Xiao C, Bandsma RH, Dash S, Szeto L, Lewis GF. Exenatide, a glucagonlike peptide-1 receptor agonist, acutely inhibits intestinal lipoprotein production in healthy humans. Arterioscler Thromb Vasc Biol 2012; 32: 1513-9.

121. Byetta (exenatide). Full Prescribing Information. Amylin Pharmaceuticals, San Diego, CA, 2011.

122. Victoza (liraglutide). Full Prescribing Information. Novo Nordisk A/S, Bagsvaerd, Denmark, 2011.

123. Kunkel D, Basseri B, Low K, et al. Efficacy of the glucagon-like peptide1 agonist exenatide in the treatment of short bowel syndrome. Neurogastroenterol Motil 2011; 23: 739-e328.

124. Buse JB, Henry RR, Han J, et al. Effects of exenatide (exendin-4) on glycemic control over 30 weeks in sulfonylurea-treated patients with type 2 diabetes. Diabetes Care 2004; 27: 2628-35.

125. Garber A, Henry R, Ratner R, et al. Liraglutide versus glimepiride monotherapy for type 2 diabetes (LEAD-3 Mono): a randomised, 52week, phase III, double-blind, parallel-treatment trial. Lancet 2009; 373: 473-81.

126. Knudsen LB, Nielsen PF, Huusfeldt $\mathrm{PO}$, et al. Potent derivatives of glucagon-like peptide-1 with pharmacokinetic properties suitable for once daily administration. $J \mathrm{Med}$ Chem 2000; 43: 1664-9.

127. Marre M, Shaw J, Brandle M, et al. Liraglutide, a once-daily human GLP1 analogue, added to a sulphonylurea over 26 weeks produces greater improvements in glycaemic and weight control compared with adding rosiglitazone or placebo in subjects with type 2 diabetes (LEAD-1 SU). Diabet Med 2009; 26: 268-78.

128. Moretto TJ, Milton DR, Ridge TD, et al. Efficacy and tolerability of exenatide monotherapy over 24 weeks in antidiabetic drug-naive patients with type 2 diabetes: a randomized, double-blind, placebocontrolled, parallel-group study. Clin Ther 2008; 30: 1448-60.

129. Parks M, Rosebraugh C. Weighing risks and benefits of liraglutide-the FDA's review of a new antidiabetic therapy. N Engl J Med 2010; 362: 774 -7 .

130. Blomgren KB, Sundstrom A, Steineck G, Wiholm BE. Obesity and treatment of diabetes with glyburide may both be risk factors for acute pancreatitis. Diabetes Care 2002; 25 : 298-302.

131. Yamamoto H, Lee CE, Marcus JN, et al. Glucagon-like peptide-1 receptor stimulation increases blood pressure and heart rate and activates autonomic regulatory neurons. J Clin Invest 2002; 110: 43-52.

132. Bose AK, Mocanu MM, Carr RD, Brand CL, Yellon DM. Glucagon-like peptide 1 can directly protect the heart against ischemia/reperfusion injury. Diabetes 2005; 54: 146-51.

133. Nikolaidis LA, Elahi D, Hentosz T, et al. Recombinant glucagon-like peptide- 1 increases myocardial glucose uptake and improves left ventricular performance in conscious dogs with pacing-induced dilated cardiomyopathy. Circulation 2004; 110: 955-61.

134. Nystrom T, Gutniak MK, Zhang Q, et al. Effects of glucagon-like peptide1 on endothelial function in type 2 diabetes patients with stable coronary artery disease. Am J Physiol Endocrinol Metab 2004; 287: E120915.

135. Drucker DJ, Erlich P, Asa SL, Brubaker PL. Induction of intestinal epithelial proliferation by glucagonlike peptide 2. Proc Natl Acad Sci U S A 1996; 93: 7911-6.

136. Baldassano S, Liu S, Qu MH, Mule F, Wood JD. Glucagon-like peptide-2 modulates neurally evoked mucosal chloride secretion in guinea pig small intestine in vitro. Am J Physiol Gastrointest Liver Physiol 2009; 297: G800-5.

137. Thulesen J, Knudsen LB, Hartmann $\mathrm{B}$, et al. The truncated metabolite GLP-2 (3-33) interacts with the GLP2 receptor as a partial agonist. Regul Pept 2002; 103: 9-15.

138. Kim W, Egan JM. The role of incretins in glucose homeostasis and diabetes treatment. Pharmacol Rev 2008; 60: 470-512.

139. Tsai CH, Hill M, Asa SL, Brubaker PL, Drucker DJ. Intestinal growthpromoting properties of glucagon-like peptide-2 in mice. Am J Physiol Endocrinol Metab 1997; 273: E77-84.

140. Tsai CH, Hill M, Drucker DJ. Biological determinants of intestinotrophic properties of GLP-2 in vivo. Am J Physiol 1997; 272: G662-8.

141. Drucker DJ, DeForest L, Brubaker PL. Intestinal response to growth factors administered alone or in combination with human [Gly2] glucagon-like peptide 2. Am J Physiol 1997; 273: G1252-62.

142. Leen JL, Izzo A, Upadhyay C, et al. Mechanism of action of glucagon-like peptide- 2 to increase IGF-I mRNA in intestinal subepithelial fibroblasts. Endocrinology 2011; 152: 436-46.

143. Dube PE, Forse CL, Bahrami J, Brubaker PL. The essential role of insulin-like growth factor- 1 in the intestinal tropic effects of glucagonlike peptide- 2 in mice.

Gastroenterology 2006; 131: 589-605.

144. Koopmann MC, Nelson DW, Murali $\mathrm{SG}$, et al. Exogenous glucagon-like peptide-2 (GLP-2) augments GLP-2 receptor $\mathrm{mRNA}$ and maintains proglucagon mRNA levels in resected rats. JPEN 2008; 32: 254-65.

145. Koopmann MC, Chen X, Holst JJ, Ney DM. Sustained glucagon-like peptide- 2 infusion is required for intestinal adaptation, and cessation reverses increased cellularity in rats with intestinal failure. Am J Physiol Gastrointest Liver Physiol 2010; 299: G1222-30.

146. Martin GR, Wallace LE, Hartmann B, et al. Nutrient-stimulated GLP-2 release and crypt cell proliferation in experimental short bowel syndrome. Am J Physiol Gastrointest Liver Physiol 2005; 288: G431-8.

147. Shin ED, Estall JL, Izzo A, Drucker DJ, Brubaker PL. Mucosal adaptation to enteral nutrients is dependent on the physiologic actions of glucagonlike peptide- 2 in mice. Gastroenterology 2005; 128: 1340-53.

148. Jeppesen PB, Hartmann B, Thulesen $\mathrm{J}$, et al. Elevated plasma glucagon-like peptide 1 and 2 concentrations in ileum resected short bowel patients with a preserved colon. Gut 2000; 47: 370-6.

149. Caddy GR, Ardill JE, Fillmore D, et al. Plasma concentrations of glucagon-like peptide- 2 in adult patients with treated and untreated coeliac disease. Eur J Gastroenterol Hepatol 2006; 18: 195-202. 
150. Chance WT, Foley-Nelson T, Thomas I, Balasubramaniam A. Prevention of parenteral nutrition-induced gut hypoplasia by coinfusion of glucagonlike peptide-2. Am J Physiol 1997; 273: G559-63.

151. Schmidt PT, Hartmann B, Bregenholt S, Hoist JJ, Claesson MH. Deficiency of the intestinal growth factor, glucagon-like peptide 2 , in the colon of SCID mice with inflammatory bowel disease induced by transplantation of CD4 $+\mathrm{T}$ cells. Scand J Gastroenterol 2000; 35: 5227.

152. Martin GR, Wallace LE, Sigalet DL. Glucagon-like peptide-2 induces intestinal adaptation in parenterally fed rats with short bowel syndrome. Am J Physiol Gastrointest Liver Physiol 2004; 286: G964-72.

153. Jeppesen PB, Hartmann B, Thulesen J, et al. Glucagon-like peptide 2 improves nutrient absorption and nutritional status in short-bowel patients with no colon. Gastroenterology 2001; 120: 806-15.

154. Jeppesen PB, Sanguinetti EL, Buchman A, et al. Teduglutide (ALX0600), a dipeptidyl peptidase IV resistant glucagon-like peptide 2 analogue, improves intestinal function in short bowel syndrome patients. Gut 2005; 54: 1224-31.

155. Jeppesen PB, Hartmann B, Hansen BS, Thulesen J, Holst JJ, Mortensen PB. Impaired meal stimulated glucagon-like peptide 2 response in ileal resected short bowel patients with intestinal failure. Gut 1999; 45: 559-63.

156. Benjamin MA, McKay DM, Yang PC, Cameron H, Perdue MH. Glucagonlike peptide- 2 enhances intestinal epithelial barrier function of both transcellular and paracellular pathways in the mouse. Gut 2000; 47: 112-9.

157. Cameron HL, Perdue MH. Stress impairs murine intestinal barrier function: improvement by glucagonlike peptide-2. J Pharmacol Exp Ther 2005; 314: 214-20.

158. Cameron HL, Yang PC, Perdue MH. Glucagon-like peptide-2-enhanced barrier function reduces pathophysiology in a model of food allergy. Am J Physiol Gastrointest Liver Physiol 2003; 284: G905-12.

159. Hadjiyanni I, Li KK, Drucker DJ. Glucagon-like peptide-2 reduces intestinal permeability but does not modify the onset of type 1 diabetes in the nonobese diabetic mouse. Endocrinology 2009; 150: 592-9.

160. Cani PD, Possemiers S, Van de Wiele $\mathrm{T}$, et al. Changes in gut microbiota control inflammation in obese mice through a mechanism involving GLP2-driven improvement of gut permeability. Gut 2009; 58: 1091-103.

161. Hsieh J, Longuet C, Maida A, et al. Glucagon-like peptide-2 increases intestinal lipid absorption and chylomicron production via CD36. Gastroenterology 2009; 137: 997-1005, e1-4.

162. Kato Y, Yu D, Schwartz MZ. Glucagonlike peptide-2 enhances small intestinal absorptive function and mucosal mass in vivo. $J$ Pediatr Surg 1999; 34: 18-20.

163. Meier JJ, Nauck MA, Pott A, et al. Glucagon-like peptide 2 stimulates glucagon secretion, enhances lipid absorption, and inhibits gastric acid secretion in humans. Gastroenterology 2006; 130: 44-54.

164. Brubaker PL, Izzo A, Hill M, Drucker DJ. Intestinal function in mice with small bowel growth induced by glucagon-like peptide-2. Am J Physiol 1997; 272: E1050-8.

165. Au A, Gupta A, Schembri P, Cheeseman CI. Rapid insertion of GLUT2 into the rat jejunal brushborder membrane promoted by glucagon-like peptide 2. Biochem J 2002; 367: 247-54.

166. Cheeseman CI. Upregulation of SGLT-1 transport activity in rat jejunum induced by GLP-2 infusion in vivo. Am J Physiol 1997; 273: R1965-71.

167. Petersen YM, Elnif J, Schmidt M, Sangild PT. Glucagon-like peptide 2 enhances maltase-glucoamylase and sucrase-isomaltase gene expression and activity in parenterally fed premature neonatal piglets. Pediatr Res 2002; 52: 498-503.

168. Stephens J, Stoll B, Cottrell J, Chang $\mathrm{X}$, Helmrath M, Burrin DG. Glucagon-like peptide-2 acutely increases proximal small intestinal blood flow in TPN-fed neonatal piglets. Am J Physiol Regul Integr Comp Physiol 2006; 290: R283-9.

169. Bremholm L, Hornum M, Henriksen BM, Larsen S, Holst JJ. Glucagon-like peptide-2 increases mesenteric blood flow in humans. Scand $J$ Gastroenterol 2009; 44: 314-9.

170. Wojdemann M, Wettergren A, Hartmann B, Hilsted L, Holst JJ. Inhibition of sham feeding-stimulated human gastric acid secretion by glucagon-like peptide-2. J Clin Endocrinol Metab 1999; 84: 2513-7.

171. Wojdemann M, Wettergren A, Hartmann B, Holst JJ. Glucagon-like peptide-2 inhibits centrally induced antral motility in pigs. Scand $J$ Gastroenterol 1998; 33: 828-32.
172. Schmidt PT, Naslund E, Gryback P, et al. Peripheral administration of GLP-2 to humans has no effect on gastric emptying or satiety. Regul Pept 2003; 116: 21-5.

173. Nagell CF, Wettergren A, Pedersen JF, Mortensen D, Holst JJ. Glucagon-like peptide- 2 inhibits antral emptying in man, but is not as potent as glucagonlike peptide-1. Scand J Gastroenterol 2004; 39: 353-8.

174. Tang-Christensen M, Larsen PJ, Thulesen J, Romer J, Vrang N. The proglucagon-derived peptide, glucagon-like peptide-2, is a neurotransmitter involved in the regulation of food intake. Nat Med 2000; 6: 802-7.

175. McDonagh SC, Lee J, Izzo A, Brubaker PL. Role of glial cell-line derived neurotropic factor family receptor alpha2 in the actions of the glucagon-like peptides on the murine intestine. Am J Physiol Gastrointest Liver Physiol 2007; 293: G461-8.

176. Sorensen LB, Flint A, Raben A, Hartmann B, Holst JJ, Astrup A. No effect of physiological concentrations of glucagon-like peptide- 2 on appetite and energy intake in normal weight subjects. Int $J$ Obes Relat Metab Disord 2003; 27: 450-6.

177. Baldassano S, Bellanca AL, Serio R, Mule F. Food intake in lean and obese mice after peripheral administration of glucagon-like peptide 2. J Endocrinol 2012; 213: 277 -84 .

178. Vrang N, Larsen PJ. Preproglucagon derived peptides GLP-1, GLP-2 and oxyntomodulin in the CNS: role of peripherally secreted and centrally produced peptides. Prog Neurobiol 2010; 92: 442-62.

179. Velazquez E, Blazquez E, RuizAlbusac JM. Synergistic effect of glucagon-like peptide 2 (GLP-2) and of key growth factors on the proliferation of cultured rat astrocytes. Evidence for reciprocal upregulation of the mRNAs for GLP2 and IGF-I receptors. Mol Neurobiol 2009; 40: 183-93.

180. Velazquez E, Ruiz-Albusac JM, Blazquez E. Glucagon-like peptide-2 stimulates the proliferation of cultured rat astrocytes. Eur J Biochem 2003; 270: 3001-9.

181. Voss U, Sand E, Hellstrom PM, Ekblad E. Glucagon-like peptides 1 and 2 and vasoactive intestinal peptide are neuroprotective on cultured and mast cell co-cultured rat myenteric neurons. BMC Gastroenterol 2012; 12: 30.

182. Iwai T, Hayashi Y, Narita S, et al. Antidepressant-like effects of 


\section{P. Janssen et al.}

glucagon-like peptide-2 in mice occur via monoamine pathways. Behav Brain Res 2009; 204: 235-40.

183. Liu X, Nelson DW, Holst JJ, Ney DM. Synergistic effect of supplemental enteral nutrients and exogenous glucagon-like peptide 2 on intestinal adaptation in a rat model of short bowel syndrome. Am J Clin Nutr 2006; 84: 1142-50.

184. Scott RB, Kirk D, MacNaughton WK, Meddings JB. GLP-2 augments the adaptive response to massive intestinal resection in rat. Am J Physiol 1998; 275(5 Pt 1): G911-21.

185. Washizawa N, Gu LH, Gu L, Openo KP, Jones DP, Ziegler TR.

Comparative effects of glucagon-like peptide-2 (GLP-2), growth hormone $(\mathrm{GH})$, and keratinocyte growth factor (KGF) on markers of gut adaptation after massive small bowel resection in rats. JPEN J Parenter Enteral Nutr 2004; 28: 399-409.

186. Booth C, Booth D, Williamson S, Demchyshyn LL, Potten CS. Teduglutide ([Gly2]GLP-2) protects small intestinal stem cells from radiation damage. Cell Prolif 2004; 37: 385-400.

187. Boushey RP, Yusta B, Drucker DJ. Glucagon-like peptide 2 decreases mortality and reduces the severity of indomethacin-induced murine enteritis. Am J Physiol 1999; 277: E937-47.

188. Boushey RP, Yusta B, Drucker DJ. Glucagon-like peptide (GLP)-2 reduces chemotherapy-associated mortality and enhances cell survival in cells expressing a transfected GLP2 receptor. Cancer Res 2001; 61: 68793.

189. Yamazaki K, Yasuda N, Inoue T, et al. The combination of metformin and a dipeptidyl peptidase IV inhibitor prevents 5-fluorouracilinduced reduction of small intestine weight. Eur J Pharmacol 2004; 488: 213-8.

190. Buchman AL, Katz S, Fang JC, Bernstein CN, Abou-Assi SG. Teduglutide, a novel mucosally active analog of glucagon-like peptide- 2 (GLP-2) for the treatment of moderate to severe Crohn's disease. Inflamm Bowel Dis 2010; 16: 962-73.

191. Jeppesen PB, Gilroy R, Pertkiewicz M, Allard JP, Messing B, O'Keefe SJ.

Randomised placebo-controlled trial of teduglutide in reducing parenteral nutrition and/or intravenous fluid requirements in patients with short bowel syndrome. Gut 2011; 60: 902-14.

192. Skarbaliene J, Petersen YM, Christjansen K, Ebbehoej K, Pedersen HD, Thorkildsen C. ZP1848, a novel GLP-2 agonist, provides a wide window of therapeutic efficacy in the experimental Crohn's disease model. Gastroenterology 2011; 140(Suppl. 1): S519.

193. Petersen YM, Jepsen T, Thorkildsen C, Larsen BD, Petersen JS, Kjolbye A. ZP1846, a novel stable, high efficacy glucagon-like peptide 2 mimetic, stimulates small intestinal growth and prevents 5-fluorouracil-induced small intestinal injury in C57BL mice. Gut 2006; 55: A48.

194. Petersen YM, Thorkildsen C, Petersen JS, Kjolbye A. ZP1846, a novel potential candidate for the treatment of chemotherapy-induced diarrhea. Support Care Cancer 2007; 15: 772-3.

195. Hargrove DM, Alagarsamy S, Qi S, et al. Pharmacological characterization of FE 203799, a novel long-acting peptide analog of glucagon-like peptide-2 (GLP-2). Gastroenterology 2011; 140(Suppl. 1): S293.

196. Schwartz LK, Seidner DL, Jeppesen PB, Pertkiewicz M, Youssef N, Heinze H. Teduglutide (TED) for the treatment of short bowel syndromeintestinal failure (SBS-IF) subjects yields further reductions in parenteral support (PS): an interim assessment of a 2-year, open-label, phase 3 trial (STEPS2). Am J Gastroenterol 2011; 106: S99.

197. Koehler JA, Yusta B, Drucker DJ. The HeLa cell glucagon-like peptide- 2 receptor is coupled to regulation of apoptosis and ERK1/2 activation through divergent signaling pathways. Mol Endocrinol 2005; 19: 459-73.

198. Bengi G, Kayahan H, Akarsu M, et al. Does glucagon like peptide-2 receptor expression have any effect on the development of human colorectal cancer? Turk J Gastroenterol 2011; 22: 388-94.

199. Iakoubov R, Lauffer LM, Trivedi S, Kim YI, Brubaker PL. Carcinogenic effects of exogenous and endogenous glucagon-like peptide- 2 in azoxymethane-treated mice. Endocrinology 2009; 150: 4033-43.

200. Thulesen J, Hartmann B, Hare KJ, et al. Glucagon-like peptide 2 (GLP2) accelerates the growth of colonic neoplasms in mice. Gut 2004; 53: 1145-50.

201. Koehler JA, Harper W, Barnard M, Yusta B, Drucker DJ. Glucagon-like peptide-2 does not modify the growth or survival of murine or human intestinal tumor cells. Cancer Res 2008; 68: 7897-904.

202. Trivedi S, Wiber SC, El-Zimaity HM, Brubaker PL. Glucagon-like peptide-2 increases dysplasia in rodent models of colon cancer. Am J Physiol Gastrointest Liver Physiol 2012; 302: G840-9.

203. Rowland KJ, Trivedi S, Lee D, et al. Loss of glucagon-like peptide-2induced proliferation following intestinal epithelial insulin-like growth factor-1-receptor deletion. Gastroenterology 2011; 141: 2166-75, e7.

204. Tee CT, Wallis K, Gabe SM. Emerging treatment options for short bowel syndrome: potential role of teduglutide. Clin Exp Gastroenterol 2011; 4: 189-96.

205. Johansen OE, Whitfield R. Exenatide may aggravate moderate diabetic renal impairment: a case report. $\mathrm{Br} J$ Clin Pharmacol 2008; 66: 568-9. 